\title{
Machine Gun Politics: Why Politicians Cooperate with Criminal Groups
}

\author{
Jessie Bullock*
}

September 28, 2021

\begin{abstract}
Why do politicians cooperate with organized criminal groups? Existing accounts explore such groups' incentives to cooperate, but largely treat politicians as either victims of violence or passive bribe takers. This paper considers why a politician may seek criminal groups' help to get votes. I argue that some politicians win elections by using an electoral strategy that I call criminal clientelism. Politicians hire criminal groups as brokers to deliver votes through two mechanisms: (1) corralling mobilizes groups of residents to the polls and (2) gatekeeping prevents rival candidates from accessing voters. I use a natural experiment that leverages exogenous variation in voter assignment to ballot boxes and a novel dataset on criminal governance to test my theory in Rio de Janeiro, Brazil. I show that corralling increases turnout and influences vote choice, and gatekeeping restricts the candidate pool. Together, the mechanisms underpinning criminal clientelism decrease competitiveness and increase the probability of victory for criminally allied candidates. I illustrate the logic of criminal clientelism using qualitative data based on more than 50 in-person interviews and thousands of anonymous voter complaints. These findings bring together the literatures on clientelism and criminal governance by demonstrating that politicians at the margin are motivated to hire violent criminals.
\end{abstract}

${ }^{*} \mathrm{PhD}$ Candidate, Department of Government, Harvard University. I am grateful to Robert Bates, Chris Carter, Kaitlyn Chriswell, Abby Córdova, Frances Hagopian, Alisha Holland, Alyssa Huberts, Steven Levitsky, Beatriz Magaloni, Ana Paula Pellegrino, and seminar participants at the Harvard Political Economy of Development Working Group, Latin American Discussion Group, Political Economy Workshop, Political Violence Workshop, and Comparative Politics Workshop. I also thank Swathi Srinivasan, João Pedro Oliveira, and May Soshi for impeccable research assistance. See here for the most recent version of this paper. Word count: 12,919 (not including Appendices or references). 


\section{Introduction}

Lucas, a veteran campaign manager, parks his car on the shoulder of the road, blocking most of the sidewalk. He walks uphill past a long line of vendors hawking fresh coconut water, churros, battery-operated Spiderman dolls, and cell phone covers sporting the logos of Rio de Janeiro's four soccer teams. The community's top drug traffickers are expecting him in the local boca de fumo (drug den). The price for Lucas' boss to campaign in this community, he heard, was $\mathrm{R} \$ 5,000$ ( $\$ 1,250$ USD) - paid to the traffickers. He carries the cash in his backpack.

This paper illustrates what politicians like Lucas' boss gain from striking deals with criminal groups. A fast-growing literature establishes that criminal organizations can influence democratic politics in Latin America (Albarracín 2018; Arias 2017; Barnes 2017; DuranMartinez 2017; Magaloni, Robles, et al. 2020; Trejo and Ley 2020; Yashar 2018). These studies highlight the range of ways criminal groups can threaten and even kill politicians or voters (Acemoglu et al. 2013; Alesina et al. 2019; Córdova 2019; Dell 2015; Mares and Young 2016), or make deals and work alongside politicians (Dipoppa 2021; Hidalgo and Lessing 2015; Tajima 2018). This literature tends to focus on what motivates the criminal group to get involved in electoral politics, but typically characterizes their political partners as passive, overlooking the reasons why they strategically strike deals with criminal groups. Yet for campaign managers such as Lucas, and the politicians they support, the reason is clear. Lucas is purchasing exclusive access to the community's voters for his boss. The deal has an expiration date: another candidate could pay up if he does not strike a deal first. So Lucas makes his way to the boca de fumo and delivers the payment, as do many other campaign managers and politicians.

Why would a politician pay an organized crime group while on the campaign trail? I argue that striking electoral bargains with criminal groups can be a winning strategy for candidates. This deal striking is the foundation of a concept I call criminal clientelism, ${ }^{1}$ born from the insight that criminal groups are a crucial and underappreciated category of political broker. Criminal clientelism can be a competitive electoral strategy; it operates through two mechanisms. Corralling leverages criminal groups' governing role to mobilize blocs of voters, via either carrots or sticks. Gatekeeping moderates territorial access to candidates. By elucidating these two mechanisms, this paper brings the literatures on criminal governance and clientelism closer together.

\footnotetext{
${ }^{1}$ I define the term in greater detail and provide a typology of criminal clientelism in Chapter 1 of my dissertation book project.
} 
To estimate the electoral returns of corralling and gatekeeping, I examine municipal elections in Rio de Janeiro, where many voters live under criminal governance. I created an original database of criminal governance by scraping and processing thousands of anonymous blog posts about criminal dominance in the city's 1,018 favelas. My database reveals which criminal groups governed which favelas from 2015-2020. I combine this with fine-grained data on exogenous voter assignment to ballot boxes to compare voting between residents who live under criminal governance and their neighbors who do not. I then leverage temporal variation in criminal dominance to show that voting outcomes co-vary with criminal presence - even within the same sample of voters. Prior research on criminal groups as brokers has been mainly descriptive. ${ }^{2}$ This study advances the literature by isolating variation at the ballot box level over space and time to precisely estimate the magnitude of criminal influence on voting.

I show that elections in criminally dominated favelas feature high voter turnout but low levels of competition. Top candidates win by a higher margin, and fewer total candidates receive votes in criminally dominated favelas, despite a higher turnout than in non-criminally dominated areas. Overall, this suggests that candidates who win in favelas have a better chance of success than similar candidates who win in non-criminally dominated areas. The dual presence of a high turnout and a smaller effective candidate pool indicate corralling and gatekeeping, respectively.

To substantiate my quantitative findings, I draw on 18 months of field research during the 2016 municipal and 2018 state elections in Rio de Janeiro. I conducted in-depth interviews with more than 50 candidates for local and state legislative office and their staffers, criminal group members, and residents of criminally dominated communities. I pair my insights from these interviews with anonymous complaint data to show how corralling and gatekeeping operate, and how they affect voters.

This paper makes three main contributions. First, by detailing politicians' incentives to hire criminal groups as brokers in the run-up to elections, it highlights important variations in criminal-politician electoral relationships, especially symbiotic ones that are poorly explained by theories of criminal governance or clientelism. ${ }^{3}$ Second, by testing two mechanisms through which criminal brokers influence voting - corralling and gatekeeping - I show empirically that criminal governance pushes voters to the polls and restricts candidates' ac-

\footnotetext{
${ }^{2}$ See Arias (2017), Albarracín (2018), Gay (1999), and Perlman (2010) for rich qualitative descriptions of the case of Rio de Janeiro. See Arias (2017), Blume (2017), and Córdova (2019) for more on the cases of Kingston, Jamaica and Medellín, Colombia, Mexico, and El Salvador respectively.

${ }^{3}$ My argument directly answers Barnes (2017)'s call for research on state-criminal interactions.
} 
cess to voters, and that these tactics influence the competitiveness of elections. Third, this paper makes an important methodological contribution. I use a novel empirical strategy to locate individual favela residents, which allows me to quantitatively estimate the effect of criminal clientelism on micro-level voting outcomes. I build on previous studies of electoral politics in favelas to develop this new approach that makes it possible to identify the causal effects of criminal governance on voting as a cross-section and over time. Future work can employ this empirical method to study voting in favelas. In the developing world, where millions of people live under criminal rule (26 million in Latin America alone), ${ }^{4}$ my overall results shed light on the implications of criminal dominance for electoral politics, inequality, and violence.

The rest of the paper is structured as follows. In Section 2, I develop the concept of criminal clientelism and present a theory that explains why politicians seek criminal groups' help to obtain votes. I describe the context of Rio de Janeiro in Section 3, and present my empirical strategies and the data in Sections 4 and 5. After presenting the results from two empirical designs in Section 6, I probe the mechanisms in Section 7 and conclude.

\section{Criminal Clientelism}

Scholars generally agree that politicians will collude with criminal groups under certain circumstances, but tend to assume that the criminals are driving such interactions. Yet crosscountry evidence suggests that politicians take deliberate actions to leverage criminal groups' abilities for electoral benefit: Italian politicians hire the mafia to deliver votes (Gambetta 1996), Taiwanese politicians recruit organized criminal groups to buy votes for them in a process known as "black gold" (Göbel 2004), and Indonesian and Jamaican politicians hire street gangs to intimidate local residents to vote (Tajima 2018; Gunst 1996; Arias 2017). Meanwhile, theories of clientelism introduce rich typologies of brokers, but often fail to include criminal organizations as a type of broker (Stokes et al. 2013; Holland and PalmerRubin 2015) or frame the transaction in terms of how the criminal brokers benefit (Acemoglu et al. 2013; Anderson 2002; LeBas 2013; Mares and Young 2016).

I bring together these disconnected literatures to claim that many politicians do "hire" criminal groups as brokers for electoral gain. They pursue criminal clientelism, which I define as an interaction between politicians and criminal groups that involves trading votes

\footnotetext{
${ }^{4}$ Preliminary estimates of the total Latin American population under criminal control are from Lessing et al. (2019).
} 
in order to influence elections. In its simplest form, candidates buy votes or turnout from criminal brokers.

Past studies tend to emphasize the costs for politicians of associating with criminal groups, and overlook their benefits. An influential wave of research based on Pablo Escobar's plata o plomo threat (the bribe or the bullet, literally, "silver or lead") conceptualizes politicians as passive actors who only engage after being coerced with the choice between violence or a bribe (Dal Bó et al. 2006). These accounts depict criminal groups as pursuing their political goals through violence (Acemoglu et al. 2013; Alesina et al. 2019; Dell 2015; Daniele and Dipoppa 2017; Trejo and Ley 2019), corruption (De Feo and De Luca 2017; Dipoppa 2021), or both (Blume 2017; Arias 2017). These studies - especially those that focus on violence - tend to highlight the cost to candidates of interacting with criminal groups. The few studies that acknowledge candidates' benefits largely do so in passing. At most, these studies show that allied politicians share in the post-victory spoils with the criminal organization (Hidalgo and Lessing 2015; Dipoppa 2021; LeBas 2013). Even studies of "armed clientelism" (Gallego 2018; Eaton 2006) and "criminalized electoral politics" (Albarracín 2018) depict the criminal group as the driver of the transaction and the politician as a silent partner.

Yet politicians have much to gain by striking electoral deals with criminal groups. A candidate in Rio de Janeiro interviewed for this study admitted that hiring criminal groups to buy votes could be an effective strategy: "The most efficient path to getting elected is getting the conscientious vote, not just buying votes every four years. But, for candidates that are trying to buy votes, negotiating with criminal groups is the most efficient way to do so." 5

My interviews confirm that candidates carefully consider the costs and benefits of working with criminal brokers. One staffer justified using criminal clientelism because it was cheaper than other electoral strategies, stating "We pay the entry fee [to the criminal group] because we need it and because it gets us cheap votes." 6 Another candidate complained that criminal groups "are much more expensive now than they were [several electoral cycles ago]... because they are more willing to use violence [against voters] today." 7 Despite complaining about the high price, this candidate added that there was "higher certainty" when striking deals with criminal groups that one would get the required votes. Six separate candidates explained

\footnotetext{
${ }^{5}$ Author's interview, Candidate 1, June 2018.

${ }^{6}$ Author's interview, Staffer 1, Rio de Janeiro, August 2018.

${ }^{7}$ Author's interview, Candidate 2, February 2019.
} 
that they were moderately afraid of the reputational $\operatorname{costs}^{8}$ of striking deals with criminal groups, but decided it was worth it because "everyone does it." 9

My candidate interviews reveal that instead of being victims or passive bribe takers, some candidates face a dilemma: hiring a criminal broker can be efficient pathway to winning an election, but carries physical, legal and electoral risks. ${ }^{10} \mathrm{I}$ build on existing arguments about brokerage relationships and criminal governance to show why hiring a criminal broker can be a winning strategy - and worth the risk - for many candidates. ${ }^{11}$

\subsection{Why Are Criminal Groups Effective Brokers?}

Under criminal clientelism, politicians hire criminal groups as brokers. To explain why leaders of criminal organizations may be particularly attractive allies to politicians, I posit that criminal brokers have many of the qualities of "organizational brokers" or "independent brokers" identified by Holland and Palmer-Rubin (2015). They are non-partisan individuals who wield influence through their roles as community leaders or through their dense social networks. Despite their access to voters, criminal groups are a relatively underexplored class of broker.

The most important reason why criminal groups can be effective brokers is that they govern territory - and the residents who live there. Criminal governance is more than the mere presence of a criminal group in an area; it implies that the criminal group is the rule-making authority and provides other governing services or institutions for residents under their control. ${ }^{12}$ While many studies have identified how criminal groups use force to push voters to the polls (Acemoglu et al. 2013; LeBas 2013), criminal governance is more encompassing than just the use of force. Criminal groups that govern territory in order to benefit their criminal business often develop ties to voters who live there through the

\footnotetext{
${ }^{8}$ The reputational fears described here parallel the audience costs described in Weitz-Shapiro (2012).

${ }^{9}$ Author's interview, Candidate 3, July 2017.

${ }^{10}$ In Chapter 2 of my book project, I develop a theory to explain why politicians engage with criminal groups despite the risks, and explore candidate-level variation in risk.

${ }^{11} \mathrm{My}$ observations build on an earlier wave of scholarship on crime and politics which argues that politicians can benefit electorally from criminal connections (Albarracín 2018; Barnes 2017; Blume 2017; Córdova 2019; Trejo and Ley 2020). However, these studies have yet to elucidate the potential mechanisms that explain why criminal groups may be effective brokers or to empirically examine politicians' returns to hiring criminal brokers.

${ }^{12}$ These services and institutions range considerably. Magaloni, Franco-Vivanco, et al. (2020) note that "symbiotic" criminal regimes provide valuable services for residents, similar to Olson (1993)'s "stationary bandits." Other "predatory" criminal regimes provide services and govern residents, yet the resident-criminal relationship is extortive and coercive.
} 
provision of services $^{13}$ (Blattman et al. 2021; Magaloni, Franco-Vivanco, et al. 2020; Lessing 2020). They are similar to ethnic patrimonial elites or local religious leaders, who may also coerce voters by controlling territory and providing services and governance (Baldwin 2015; Koter 2013; Kramon 2016). ${ }^{14}$ Criminal organizations, like chiefs, are not democratically elected but have the qualities that Koter (2013, p. 195) observes in chiefs with considerable electoral sway: they "affect the well-being of those around them" and "enjoy a substantial amount of deference." The power that criminal groups wield in their communities makes them potentially highly effective brokers.

Another quality that makes criminal groups particularly attractive brokers to candidates is that they are independent from particular political parties, and can unlock access to voters who are not reachable through party machines. Recent studies suggest that non-partisan brokers can be highly effective because they already have considerable influence over their own groups of voters (Zarazaga 2014). But given their freedom from party ties, independent brokers such as criminal groups must receive sufficient compensation to motivate them to put in the necessary effort (Novaes 2018; Camp 2017). Since these types of brokers are not loyal to individual parties, they can act as free agents, and ultimately mobilize votes for the politician or party that offers the best price (Holland and Palmer-Rubin 2015; Gay 1999). Candidates in Rio de Janeiro recognize that criminal groups do this too by selling votes in the community they govern to the highest bidder. Candidates and staffers confirmed in interviews that a deal with a criminal group could make or break an election, emphasizing the criminal broker's ability to negotiate and the returns to the deal once it is made. In an interview, a candidate told me, after not being able to afford to pay a criminal group's bribe (and therefore not receiving access to a community), "I knew if I didn't, someone would... they would find someone willing to pay it." 15

Where criminal organizations govern, standard explanations of how clientelism works may no longer be sufficient to describe the electoral dynamics among candidates, criminal brokers, and voters. We do not have a theory that adequately describes the type of contractual relationship between a politician and a violent group that controls so many facets of voters' civic lives. I suggest two new mechanisms through which criminal brokers use their territorial control and non-partisan affiliation to deliver votes: corralling and gatekeeping.

\footnotetext{
${ }^{13}$ Criminal groups that are not territory based, and subsequently do not have ties to a defined pool of voters, are beyond the scope of this paper.

${ }^{14}$ Baldwin (2015) notes that traditional chiefs in Zambia have coercive power over voters and provide for voters at the group level, using these powers to influence voters in their village as development brokers.

${ }^{15}$ Author's interview, Candidate 1, June 2018.
} 
Figure 1: Structure of the Argument

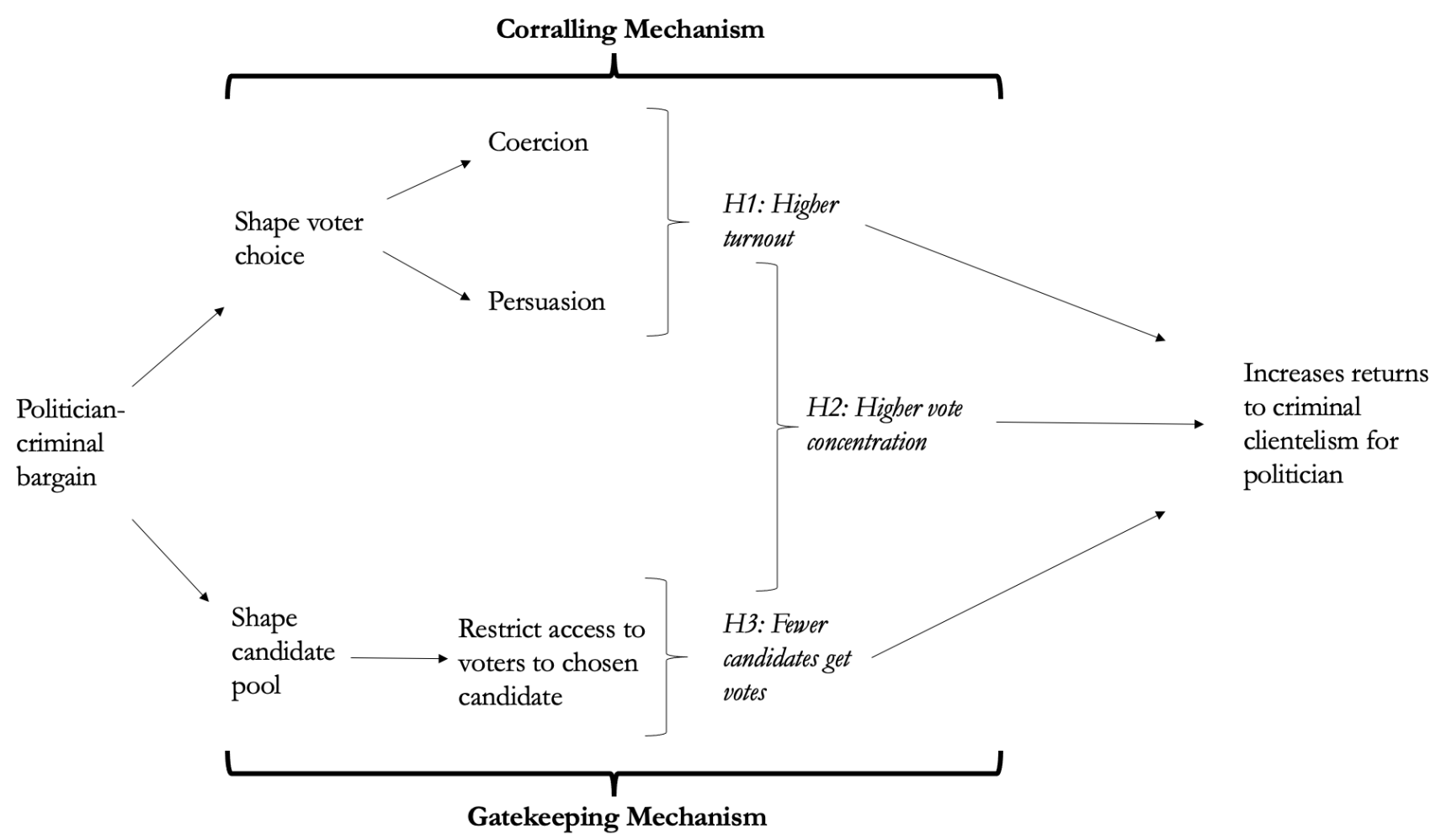

Figure 1 illustrates my argument, which I describe below. My three hypotheses suggest that criminal clientelism - when successful - increases the returns on candidates' investment. Criminal brokers who can deliver low competition and high-yield electoral outcomes are likely to be perceived as effective by candidates looking to hire a broker, and a candidate may be more likely to decide that the benefits of partnering with organized crime outweigh the costs. The summary outcome that corresponds to both mechanisms, vote concentration (H2) and the two mechanism-specific outcomes (H1 and H3) are italicized in the center of the diagram.

\section{$2.2 \quad$ Voter Corralling}

One way in which criminal brokers affect electoral outcomes is by corralling - pressuring groups of voters to the polls. My theory builds on previous work that shows candidates buy group-level outcomes when they lack the capacity to monitor and enforce clientelistic bargains at the individual level. ${ }^{16}$ Yet corralling differs from standard group-based vote

\footnotetext{
${ }^{16}$ Candidates buy votes "wholesale" from ethnic groups in Africa (Kramon 2019), target benefits at the group level in Senegal (Gottlieb and Larreguy 2020), drive voters to the polls in Liberia (Bowles et al. 2020),
} 
buying in that it is premised on criminal groups' territorial control. Successful corralling can generate higher turnout rates and greater vote concentration (a larger share of votes goes to one or a few top candidates) in areas under criminal governance.

I argue that criminal brokers corral voters in two different ways: by using coercion (negative inducements) and persuasion (positive inducements) (Mares and Young 2016). First, criminal groups coerce voters to the polls by using the credible threat of violence. ${ }^{17}$ Even when threats are targeted, they raise the stakes of defection for all individuals living in criminally controlled territory. Second, criminal groups persuade voters to go to the polls by buying their turnout or convincing them that the candidate will deliver goods to the community. ${ }^{18}$ Persuasive strategies are rarely targeted, and may even be publicized by the criminal groups within criminally dominated communities (e.g., a voter must show a cell phone picture of their electronic vote to the criminal broker in exchange for a specific sum of money). These two strategies, coercion and persuasion, are not mutually exclusive, and criminal groups can use both to corral voters, as shown in Figure 1.

Criminal groups have the power to effectively coerce and persuade at the group level because of their control over territory and governance. Criminal groups' level of influence sets them apart from other classes of brokers who, lacking the resources to pursue their preferred option of targeting individuals, monitor voters at the group level. This is not the case with criminal groups, whose threats or handouts - even individual ones - may diffuse to individuals with whom they do not engage directly. Since criminal groups are - in most cases in which they operate - the main actor responsible for voters' day-to-day welfare, we can expect local residents to take threats or promises of rewards (e.g., side payments) very seriously, and for news of them to spread quickly through the area under control. Corralling voters through group-level coercion and persuasion thus relieves criminal brokers of clientelism's classic problem of monitoring at the individual level and reduces efficiency losses (Hicken and Nathan 2020; Stokes et al. 2013).

When making deals with candidates, criminal groups often sell their ability to corral an entire community. The criminal broker sets a flat rate for the community's votes, rather than subcontracting on a per-vote basis. It has been well documented that local criminal groups in Rio de Janeiro set the price of access to voters at the group level, calling their groups

and monitor groups of voters in small districts in Colombia (Rueda 2017).

${ }^{17}$ Other studies of organized crime in politics have noted the use of group-level violence against voters in Mexico (Trejo and Ley 2020), Colombia, (Acemoglu et al. 2013), and Brazil (Arias and Barnes 2017; Albarracín 2018; Hidalgo and Lessing 2015).

${ }^{18}$ Prior research has documented the existence of protection rackets that entail buying votes or loyalty for their preferred candidates in Indonesia (Tajima 2018), Sicily (Gambetta 1996) and Japan (Hill 2004). 
of voters "electoral corrals" (currais eleitorais) (Araújo and Otávio 2018). The candidates who pay the flat rate for the neighborhood get exclusive or nearly exclusive access to the neighborhood's voters. In some areas, the criminal group will perform other brokerage duties for an additional payment, such as hosting campaign events or door-to-door canvassing on election day.

The candidate and criminal broker can then easily measure the effectiveness of their corralling efforts by looking at the two observable implications of the practice: turnout and group-level electoral returns. First, a candidate will hope for high turnout levels, since they purchased the bloc votes as a flat fee. Each additional voter who turns out (and votes for them, as I explain in below) lowers the marginal cost per vote. High turnout rates are one way to measure whether corralling was successful and if the coercive or persuasive appeals, at a minimum, pushed more voters to the polls. I hypothesize:

H1: In areas where criminal groups govern, voters will turn out at a higher rate.

Yet determining whether corralling was successful requires examining more than the turnout rate. For a candidate, buying a community of voters that turns out in large numbers is useless, and even detrimental, if the voters are not turning out for them. The candidate will also hope that the returns show that corralling shaped residents' eventual vote choice. In most contexts where the ballot is secret, including Rio de Janeiro, candidates or criminal brokers cannot observe individual vote choices. They can measure group-level returns at the ballot box and tabulate the number of votes received as a share of the total ballots cast. Group-level returns that are highly "concentrated," meaning that a large share of votes went to one or a few top candidates, would indicate that corralling efforts were successful. I hypothesize:

H2: In areas where criminal groups govern, vote returns will be concentrated on a single or small number of candidates.

High turnout and high vote concentration jointly indicate that criminal corralling pushed people to the polls for a specific candidate. For a candidate, corralling that both sways undecided voters to vote for them and coaxes nonvoters to the polls for them is a high-yield investment - and potentially a winning electoral strategy.

These empirical implications distinguish my theory from other electoral behavior. These two outcomes - high vote concentration and high turnout - are not commonly seen together. 
On the contrary, the relationship between vote concentration and turnout is more often the reverse. Several studies (Cox et al. 2020; Smith 2018; Geys 2006) argue that as the vote becomes more diffuse between competitors and the race gets closer, turnout increases. However, I expect that when criminal groups corral, low competition will accompany high turnout due to criminal groups' ability to coerce and persuade.

Lastly, I expect that vote concentration, but not turnout, is also affected by other factors that lower competition, such as gatekeeping, which I describe in the next section. As such, vote concentration is best thought of as a summary indicator that broadly measures criminal brokers' influence on voting outcomes (see Figure 1). I expect changes in turnout, however, to only be affected by voter corralling.

\subsection{Candidate Gatekeeping}

The second way in which criminal brokers affect electoral outcomes is by gatekeeping, or shaping the candidate pool. By restricting voters' access to their chosen candidates, criminal groups indirectly shape the information that voters have about the candidate pool. Though criminal brokers do not prohibit voters from learning about other candidates, they make it more difficult; thus local residents likely receive a disproportionate amount of information about the criminal group's candidate and little or no information about others. The observable implications of gatekeeping are that fewer candidates are known, and thus fewer receive votes in the neighborhood; this generates a higher vote concentration among the known candidates.

Informational theories of clientelism emphasize that candidates hire brokers to signal their electoral viability or credibility (Kramon 2016; Muñoz Chirinos 2019). The information voters receive at campaign events or via printed materials plays a decisive role in determining electoral outcomes by shaping their perceptions of candidates and indirectly affecting their vote choice.

Criminal brokers shape information through two channels: by providing information about favored candidates to voters, and by obstructing other candidates' access to voters. The first channel resembles informational theories of clientelism, according to which brokers target information about their preferred candidate at campaign events, via printed materials, or through other media channels. The second channel - preventing rival candidates from accessing voters - remains unexplored. Since criminal brokers control territorial access to the voters they govern, they can grant their candidate access to voters and obstruct access to the rest. Restricting information about rival candidates biases the information voters receive 
during the campaign towards the criminal broker's chosen candidate; further downstream, this channel indirectly shapes vote choice and election outcomes.

The benefits of hiring a criminal group rather than other brokers to gatekeep may be particularly salient in cognitively burdensome elections in which little is known about the candidates. Hundreds of candidates run in Rio de Janeiro's state and local legislative elections, and it is nearly impossible for voters to be familiar with all the candidates running (explained in greater detail in Section 3.1). Candidates in lower-level races, such as state deputy or city councilor, receive little press, and thus word-of-mouth and grassroots mobilization efforts can have a greater impact than for those in high-profile races, such as senator or mayor. Voters often only learn that a candidate is running if that candidate is able to distribute promotional materials in their neighborhood. Several residents of criminally dominated communities told me that criminal groups use force to prohibit other brokers' candidates from accessing voters or require other brokers to get their candidate "approved" by the criminal group. Unapproved candidates are forced to campaign without publicity, mainly within their network of friends and family. If hiring a criminal group to gatekeep can keep rivals away from voters and guarantee a larger share of the vote, partnering with a criminal group may seem more appealing to a candidate and increase the returns to criminal clientelism.

When gatekeeping is effective, I expect fewer candidates to receive votes in criminally dominated communities and for the vote share to be more concentrated. When gatekeeping obstructs rivals' access to voters, it reduces the number of candidates that voters learn about, placing a higher burden on the voter to learn about unendorsed candidates. The observable implication of the (lack of) information about candidates is that fewer candidates to receive at least one vote, which is reflected in the following hypothesis:

H3: In areas where criminal groups govern, fewer candidates will receive at least one vote in the community.

Along with the other observable implication elaborated in $\mathbf{H 2}$, high vote concentration, a measure of gatekeeping should consider the number of candidates that receive at least one vote. This is because standard measures of vote concentration do not clearly represent the number of candidates on which voters have information. ${ }^{19}$ I expect successful gatekeeping

\footnotetext{
${ }^{19}$ For example, vote concentration in one ballot box ("Ballot Box A") where three candidates split the vote will be the same as vote concentration in another ballot box ("Ballot Box B") where one candidate wins $50 \%$ of the vote share and $20+$ candidates carve out a handful of votes each. By analyzing the number
} 
to increase the concentration of votes for the chosen candidate and to reduce information about candidates who receive few votes, eliminating them from the neighborhood's effective candidate pool. Both outcomes in $\mathbf{H 2}$ and $\mathbf{H 3}$ are necessary to evaluate this hypothesis.

\subsection{Alternative Explanations}

A vast body of scholarship unrelated to the study of criminal governance could explain why voters who live under criminal rule mobilize for a particular candidate. The first set of alternative hypotheses consists of a series of vulnerability-based explanations. These explanations have long identified poor voters as more susceptible to clientelism (Scheiner 2007; Auyero 2001), and have recently distinguished between the poor and the poorest voters, those who live in slums and informal settlements, who may be exposed to intense clientelism or politicized access to resources (Murillo et al. 2021; Holland 2016; Zarazaga 2014). Criminal groups are also more likely to govern slums and informal settlements. One alternative to my theory is that criminal groups govern the type of voters that are simply the most responsive to vote buying or coercion, but these voters are not necessarily responding to the criminal group.

A second set of voters' agency-based hypotheses focuses on bottom-up explanations of how the poorest voters use their scarce resources to select their brokers and candidates. These include demands for goods and services between elections using relational clientelism (Nichter 2018), strategically selecting brokers within slums to leverage their collective power (Auerbach and Thachil 2018), and leveraging their majority size in districts to demand public goods (Cooperman 2020). If true, this explanation could indicate that voters are coordinating independently of the criminal group. I consider both of these explanations while empirically testing my argument.

\section{Politicians, Criminal Brokers, and Voters in Rio de Janeiro}

This section details the context of my study, specifically elections and criminal governance in Rio de Janeiro.

of candidates that receive votes, we see that voters in Ballot Box B have heard of at least 21 candidates, whereas we only have evidence of voters in Ballot Box A knowing three. 


\subsection{Politicians in Rio de Janeiro}

This paper focuses on subnational legislative elections because a criminal group's support may more easily tip the scale in such contests than in an executive election for mayor or governor or a national race. Brazil's electoral rules facilitate intense competition for votes. Legislative elections follow an open-list proportional representation system, and take place in multimember single districts. Though candidates often informally carve out their own redutos ("electoral fortresses") of neighboring communities (Ames 2009), all candidates are elected at-large and represent the entire state or municipality, depending on the election. Political parties may submit up to 1.5 times the number of candidates for each at-large seat. Given Brazil's weak party system and the large number of parties vying for seats (Mainwaring 1998; Mainwaring et al. 2018), thousands of candidates may run for legislative office. Some are serious candidates who will win handily, others are laranjas (non-viable candidates) who garner a small number of votes to add to the party's total vote share, and many are on the margin, where a few thousand votes can mean the difference between winning and losing the race. I expect these candidates on the margin to benefit the most from - and therefore be most likely to use - criminal clientelism as an electoral strategy.

Rio de Janeiro has 51 city council seats. If every political party submitted the maximum of 1.5 times the number of seats, 77 affiliated candidates could run for city council from each party. In the 2016 city council election, 1,628 candidates affiliated with 35 different parties competed for the 51 seats (the mean party fielded 46.5 candidates, while eight political parties fielded the maximum number of candidates).

The proliferation of candidates means that dozens, if not hundreds, of candidates are on the margin for each legislative race, and that every vote matters. Since many elections are decided by a margin of fewer than 1,000 votes, one ballot box can make or break an election. Figure 2 illustrates the closeness of the 2016 Rio de Janeiro city council race. Though some clear favorites won by a landslide, many barely won - and many more barely lost - by fewer than 1,000 votes. The horizontal dashed line at 6,000 votes represents the minimum number of votes received by a winning candidate. In this race, 30 candidates fell within 1,000 votes of this threshold, and 66 candidates - more than the size of the entire council - fell within 2,000 votes of it. Candidates like this who are on the margin will likely be fighting to get as many votes as they can. 
Figure 2: Most Voted Candidates in 2016 Rio de Janeiro City Council Election

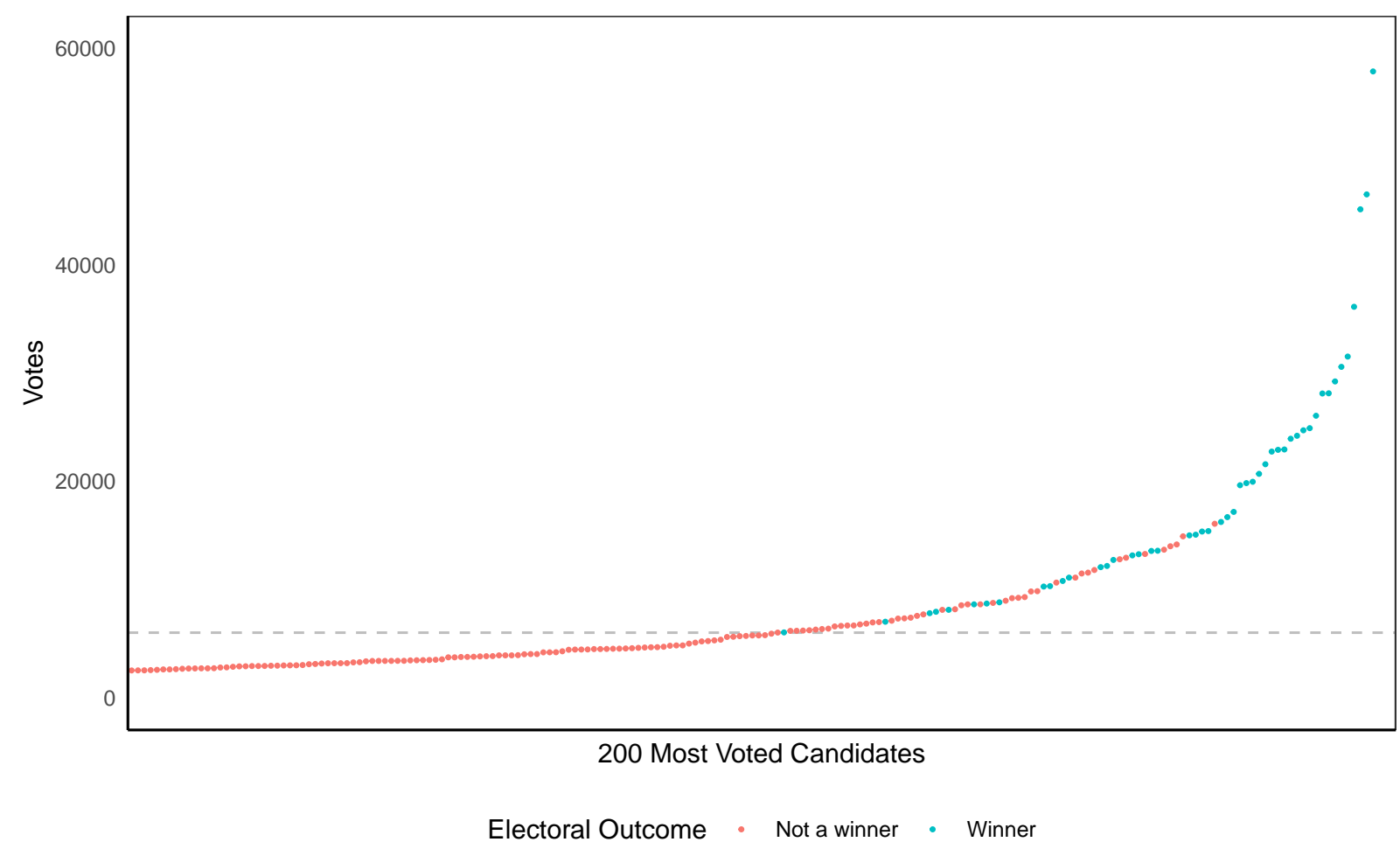

Note: The figure plots the number of votes earned for candidates in the single-district city council election in Rio de Janeiro in 2016. I trim the y-axis for readability, and exclude the three candidates who won by the largest margin (receiving 106,657 votes, 90,473 votes, and 71,468 votes). Source: TSE.

\subsection{Criminal Governance in Rio de Janeiro}

Satriano (2020) estimates that criminal groups govern $57 \%$ of voters in Rio de Janeiro, approximately 3.7 million of the city's 6.74 million inhabitants. These voters live in hundreds of criminally dominated communities of various sizes, primarily favelas, which are scattered throughout the city. Favelas are densely populated, lower-income settlements that are characterized by incredibly high population density and poor-quality infrastructure, service delivery, and public security (Perlman 2010). The government neglected residents in favelas long before the birth of today's criminal groups (Zaluar 1994), but some of these inequalities have widened as criminal groups began conducting their illegal operations where the state had little or no presence. After decades of unequal development vis-à-vis the rest of the city, most of the city's 1,018 favelas are now governed by organized criminal groups.

Two main categories of criminal groups govern these favelas. The first is drug trafficking organizations, which use the favelas they control for tasks related to their drug businesses, 
such as storing or packaging drugs, moving drugs through the supply chain, or selling them (Arias 2006). Each favela governed by one of the three major drug trafficking organizations ${ }^{20}$ operates as a decentralized member of a network, somewhat like a franchise. The entire network benefits from increases in territorial control; at the favela level, this means that there are more nearby reinforcements to call if needed and possibly fewer close rivals in the case of a takeover.

The second type of criminal group in Rio de Janeiro is vigilante-style extortion rackets, called milícias (Cano and Duarte 2012). The milícias - often associated or formerly associated with law enforcement - extort residents and local businesses for "security" payments and control access to utilities services, transportation, and loans. Milicías are also very decentralized; neighborhood-level leaders call the shots in their communities, and they can obtain reinforcements from other leaders when fighting traffickers if need be. Milicías benefit linearly from controlling more territory (and people): the more residents they control, the more protection rents they can collect, and the higher their profits.

Across the city, there are hundreds of tiny "criminal kingdoms" that govern residents. Each favela's criminal leader has significant autonomy to dictate the day-to-day rules and agreements governing residents in their territory. Magaloni, Franco-Vivanco, et al. (2020) note five governing styles that influence how criminal groups treat residents and law enforcement in their territory, but there may also be variation among groups of the same type that govern different favelas. Each criminal group leader in a different favela will have a distinct set of arrangements with drug suppliers (if they sell drugs) that depends on their estimated sales. Local neighborhood association leaders will liaise between them and residents, or with police and bureaucrats who operate in their area.

\subsection{Voting in Rio de Janeiro's Favelas}

Rio de Janeiro's favelas have the potential to be politically powerful solely due to the volume of people who live there (Gay 1993). Voters who live in these territories can be a powerful force at the ballot box if they coordinate (Perlman 2010) or are coordinated by a broker (Gay 1999). So many people live in favelas today that they could singlehandedly elect several politicians for legislative office. In 2020, the candidate elected to Rio de Janeiro's city council with the fewest votes (all members are at-large) won with just over 10,000 votes. In Rocinha, Rio de Janeiro's most populous favela, there are approximately 70,000 registered

\footnotetext{
${ }^{20}$ These are ADA (Amigos dos Amigos, Friends of Friends), CV (Comando Vermelho, Red Command), and TCP (Terceiro Comando Puro, Third Pure Command).
} 
voters. Rocinha voters (or those from smaller favelas) could theoretically join forces to elect several representatives from their communities.

The highly localized nature of criminal governance in favelas matters for electoral politics. Criminal clientelism deals also vary by favela: if a candidate pays a criminal group for votes in one, this does not purchase access to all favelas dominated by that faction. A candidate described paying criminal leaders for "private security" to safely campaign in two neighboring favelas dominated by the same faction. He noted that he did not expect to gain votes in many other favelas governed by the same faction because he did not have access to safely campaign there.

\section{Research Design}

I measure the effect of criminal governance on voting, across favelas and over time, to explore the returns to corralling and gatekeeping. I use quasi-experimental causal evidence to estimate the electoral consequences of criminal clientelism, and support these results with text-based data and qualitative interviews that suggest corralling and gatekeeping behaviors are driving the effect.

A key assumption underpinning these strategies is that criminal governance is restricted to Rio de Janeiro's favelas. While criminal governance is not necessarily a feature of all favelas, criminal groups govern most favelas, and thus favela voters. In favelas controlled by criminal groups, this power usually only extends to the favela boundary. Most of the city is so developed that the territorial boundaries of criminal groups' rule are constrained by adjacent state-governed areas or natural barriers. ${ }^{21}$

This paper improves on existing point estimates of the effect of criminal dominance on voting behavior in two ways. First, I solve the problem of measuring which voters live under criminal governance by exploiting exogenous variation in ballot box assignment. I use a natural experiment to compare voting patterns between residents of criminally controlled vs. non-criminally controlled areas (left panel of Figure 3). This design yields the most

\footnotetext{
${ }^{21}$ There are two important exceptions. The first is the West Zone of the city, where milícias have a strong presence in underdeveloped neighborhoods and expand outward. Despite their growth, the assumption is still valid because favela boundaries are frequently redrawn, clearly showing that these western favelas are increasing in size. Geographers at the municipal data collection agency IPP (Instituto Pereira Passos), described in Section 5.1, redraw the official limits of favelas every year using satellite imagery to account for these expansions. The second exception is in small to medium-sized municipalities moving inland in Rio de Janeiro state, where criminal groups often annex entire lower- to middle-class neighborhoods. These are outside the scope of my study, which focuses on the municipality of the capital city Rio de Janeiro.
} 
precise estimates of the effect of criminal dominance by leveraging exogenous variation in the fraction of favela voters casting their votes in each ballot box. However, this could be considered a bundled treatment, because the comparison group does not live in a favela and does not live under criminal rule.

Second, I isolate the effect of criminal governance on voting from the impact of broader variables associated with favela life. I use a difference-in-differences design to leverage temporal variation in criminal dominance between favelas (right panel of Figure 3). In the figure, the purple circles indicate the treatment units of interest (voters living under stable criminal governance) and the green triangles denote the control units of interest (voters living under contested criminal governance).

I then supplement these quantitative strategies with qualitative evidence to elucidate the corralling and gatekeeping mechanisms that draws from extensive interviews, candidate shadowing, and anonymous complaints that reveal voters' everyday experiences in criminally governed neighborhoods.

Figure 3: Quantitative Empirical Strategies

Strategy 1: Random Ballot Box Assignment

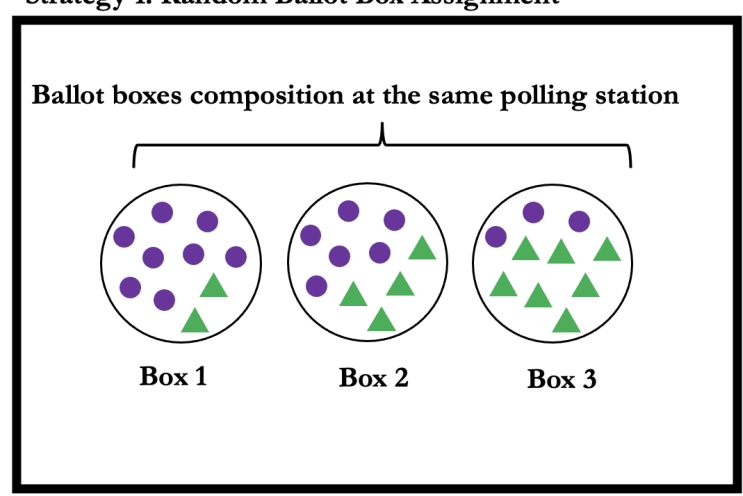

Strategy 2: Difference-in-Differences

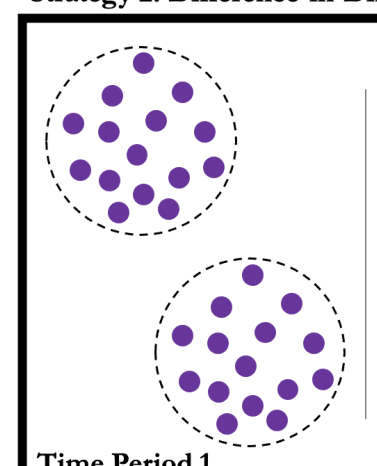

Time Period 1

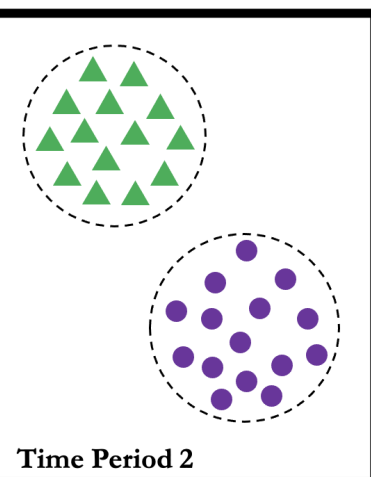

Time Period 2
Voter living in criminally controlled territory
$\Delta$ Voter living in non-criminally controlled territory
Ballot box

-.-- Favela boundary

Note: This diagram depicts the two key identification strategies used to estimate the effect of criminal governance on voting. The left panel shows a natural experiment that leverages exogenous variation in voter assignment to each ballot box within polling stations. In this simple example, at a polling place with three ballot boxes, Box 1 will have the highest share of voters living under criminal rule and Box 3 will have the lowest. This share is exogenously determined. The second panel illustrates a simplified version of my difference-in-differences estimation strategy, which leverages temporal variation in criminal governance

to compare favelas that maintain a constant criminal regime with those that change criminal regimes. 


\subsection{Empirical Strategy 1: Exogenous Ballot Box Assignment}

The first strategy addresses a measurement problem: how can we determine how individuals who live in criminally controlled favelas vote? Ideally, my hypotheses would be evaluated by randomly assigning voters to live under the criminal governance "treatment," and then measuring voting behavior, but this is clearly impractical and unethical. Instead, I approximate the ideal by leveraging an exogenous ballot box assignment procedure, which I explain in more detail in Appendix A1 and summarize here.

In Brazil, each polling place (school, community center, etc.) contains multiple ballot boxes. Voters are quasi-randomly assigned to one of any number of polling places near their home, which makes it impossible to estimate the effect of criminal governance based on residential address or neighborhood alone. In other words, a voter's residential address in Brazil does not determine their assigned voting location. Voters are allocated to one of several nearby polling stations - and subsequently, ballot boxes - through an as-good-asrandom assignment procedure conducted at the federal level. Thus, voters who live in the same criminally controlled favela - and even the same city block - often vote at different locations, and intermingle at the ballot box with voters who do not live under criminal governance. The geographic fuzziness in polling place assignment has been an obstacle in past studies of favelas, which have attempted to overcome this problem by classifying polling stations using a binary scheme (e.g., either inside or outside of a favela's buffer zone) (Hidalgo and Lessing 2015; Nascimento 2017; Ricci 2020).

To address this challenge, I use new data to determine how many individual voters per ballot box live in a favela. I filed an information request with the ombudsman's office of the Regional Electoral Tribunal of Rio de Janeiro (TRE-RJ) for data indicating the proportion of voters per ballot box that lived in postal codes located inside favelas. ${ }^{22}$ I provided the ombudsman's office with a list of postal codes I geocoded in criminally dominated favelas in order to calculate a precise measure of the share of favela voters per ballot box.

I then leverage an imbalance that results from quasi-random ballot box assignment once voters are already assigned to a polling station. This imbalance, due to the exogenous assignment procedure, means that different ballot boxes - in the same location - will have different proportions of voters that live in favelas. My approach looks inside polling places and estimates within-polling-station differences in voting behavior between voters who live in favelas vs. those just outside them. The exogenous imbalance in the share of favela

\footnotetext{
${ }^{22}$ In Brazil, the post office uses nine-digits postal codes, which may be as small as a city block. Each favela contains several postal codes.
} 
voters at any one ballot box allows me to identify the causal effect of favela residency on voting as if it were a natural experiment. To isolate the effect of favela residency on voting behavior, I estimate the following pooled equation where $i$ corresponds to each ballot box and $t$ corresponds to four different election years:

$$
Y_{i t}=\alpha+\beta_{1} \text { ShareFavela }{ }_{i t}+\pi_{p}+\rho_{f}+\gamma_{t}+\epsilon_{p t}
$$

where $Y_{i t}$ represents one of three electoral outcomes, described in greater detail in Section 5.2. ShareFavela $a_{i}$ is a continuous variable representing the share of voters at the ballot box that lives in the favela, determined using the exogenous assignment procedure explained above. I include polling station intercepts $\left(\pi_{p}\right)$, favela-level intercepts $\left(\rho_{f}\right)$, and election-year intercepts $\left(\gamma_{t}\right)$, and cluster standard errors at the polling-station-year level. The coefficient of interest is $\beta_{1}$.

This method is much more precise than approaches used in past studies. This study goes beyond the binary classification of polling stations in Rio de Janeiro as "favela" or "not favela" (Hidalgo and Lessing 2015; Nascimento 2017; Ricci 2020). My approach allows me to confidently measure voting outcomes for favela residents vs. non-favela residents, rather than guessing which of the several nearby polling stations has the highest concentration of favela voters. Since the share of favela voters is a continuous variable, I am also able to estimate the effect of favela residency on voting outcomes more precisely than a binary indicator. In

quantitative studies in other parts of the world, the treatment is generally assigned at the municipality level (Acemoglu et al. 2013; De Feo and De Luca 2017). This empirical design allows the treatment assignment to be much more granular, precisely identifies which voters are under criminal control and which are not.

\subsection{Empirical Strategy 2: Changes in Criminal Governance Over Time}

The second strategy addresses challenges to inference regarding the bundled treatment of favela residency and living under a criminal governance regime. The precise within-ballot box estimates from Equation 1 - despite being conditionally random - do not separate the "criminal governance" effect from the "favela residency" effect. Recall that vulnerabilitybased and voters' agency-based explanations of vote choice focus on the same pool of favela residents who are governed by criminal groups. In this design, I analyze how poor, vulnerable residents' voting behavior varies over time when the only favela-level variable to change is 
the stability and reach of criminal rule.

I tackle this challenge to inference by studying temporal variation in criminal governance while holding the favela, voters, and other geographic covariates constant. I leverage granular variation in my criminal dominance database to identify a subset of favelas that sustained the same criminal leadership in the 18 months prior to the 2016 municipal election, and compare voting outcomes with those in favelas that were not clearly governed by any criminal group leading up to the election. I examine changes in voting behavior between the two groups.

To select my sample of favelas, I focus on the North Zone of the city, an area where substantial criminal conflict occurs in close geographic proximity, and where all three drug trafficking gangs and milícias dominate communities (see Figure 4). I use matching ${ }^{23}$ to select a sample of stable favelas that are clearly governed by one criminal group - and have been for at least 18 months - and contested favelas, which recently changed stripes, underwent a turf war, or whose leaders are engaged in an internal power scramble. The matched sample covers 12 favelas, six with stable criminal governance and six with contested governance. These 12 favelas encompass 652 ballot boxes across 91 polling stations where between 214,000-220,000 favela residents and the surrounding lower- to middle-class residents vote. All six favelas in the stable criminal governance "treatment" group have experienced constant criminal leadership since at least January 2015, whereas those in the contested criminal governance "control" group changed criminal leadership in the six months prior to the 2016 election.

I use a difference-in-differences framework to exploit temporal and spatial variation in criminal governance across these 12 favelas. I compare electoral outcomes in the municipal election of 2012, when all favelas were stably governed by criminal groups, ${ }^{24}$ to those in 2016 , when only six favelas were governed by a clear criminal leader. The estimating equation for this model is:

$$
Y_{i t}=\alpha+\beta_{1}\left(\text { CrimControl }_{f} \times \text { Year }_{t}\right)+\beta_{2} \text { ShareFavela }_{i t}+\pi_{p}+\epsilon_{p}
$$

where $Y_{i t}$ is one of three electoral outcomes of interest for ballot box $i$ in election year $t$. $\mathrm{CrimControl}_{f}$ takes on a value of 1 for favelas that had strong criminal governance during the elections (i.e., their criminal faction had not changed since at least January 2015), and a value of 0 for favelas that recently experienced a turf war and changed hands. Year $_{t}$ corresponds

\footnotetext{
${ }^{23}$ I use coarsened exact matching across favela population, number of ballot boxes residents vote in, and original criminal group leadership (Iacus et al. 2009).

${ }^{24}$ Though my criminal governance database does not extend back to 2012 across the entire city, I confirm with other cross-sections that favelas in the "stable" sample were stably governed in 2012.
} 
Figure 4: Map of Stable and Contested Favelas

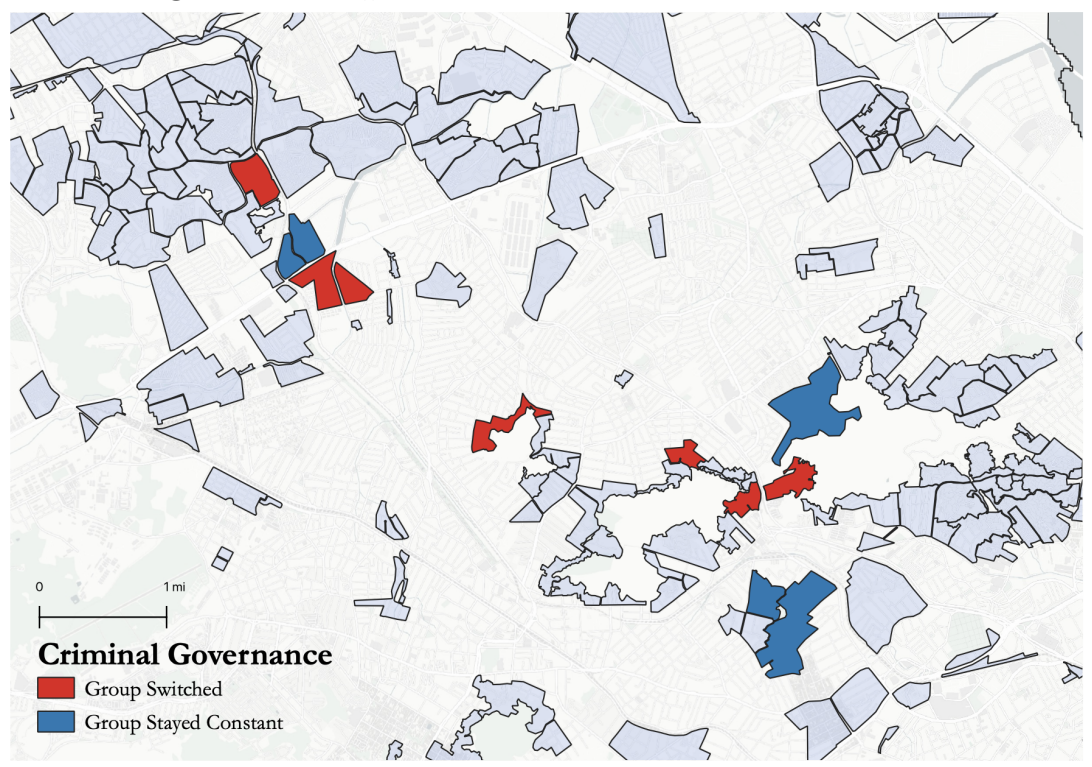

Note: This map shows the selected favelas in the sample that maintained stable criminal governance from 2012-2016 and those that moved from constant to contested criminal governance in 2016. The favelas that stayed stable are: Morro do Carmo, Teófilo Mesquita, Complexo da Coréia, Morro do Urubu, Morro do Chaves, Joana D'Arc. Those that became contested are: Faz Quem Quer, Proença Rosa, Parque Mundial, Terra Nostra/Terrinha, Juramentinho, Matadouro Juramento, Rodo Juramento. Source: author's elaboration. Base map is OpenStreetMap.

to either the 2012 or 2016 election year, and I include polling-station-level intercepts $\left(\pi_{p}\right)$, the share of residents living in the favela, and cluster standard errors at the polling station level $\left(\epsilon_{p}\right)$, controlling for temporal variation. $\beta_{1}$ is the coefficient of interest.

\subsection{Empirical Strategy 3: Qualitative Evidence}

Over the course of 18 months, I conducted fieldwork during and after two election cycles in Rio de Janeiro to establish the plausibility of each mechanism and how they relate to candidate incentives. I marshal qualitative data to support my claims that corralling and gatekeeping are driving the point estimates from equations 1 and 2 .

My primary focus with my qualitative research is to show how candidates think about risk when considering striking a deal with a criminal group. To analyze their risk assessments, I conducted ethnographic fieldwork and semi-structured interviews ${ }^{25}$ with candidates, local favela community leaders, police, and select criminal group members. These semi-structured

\footnotetext{
${ }^{25}$ To recruit my initial sample, I attended neighborhood association meetings, community security council meetings, and party-affiliated candidate information sessions, all of which helped me identify more than 50 individuals to interview in purposeful snowball samples within different social or political networks.
} 
interviews captured their observations about how campaigns worked broadly as well as in criminally dominated favelas, what makes a candidate likely to succeed at the polls, and, if applicable, their individual experiences with political campaigns in these areas. Using the candidate contact lists I collected by attending party events, I then conducted 37 structured interviews with candidates for state deputy (the lowest state-level legislative office) during and immediately after the 2018 campaign. These structured interviews included more pointed questions about their strategy for reaching favela voters, their "security" detail inside favelas (if applicable), and whether they had been threatened by criminal groups when trying to campaign in a favela. I asked questions about corralling and gatekeeping in broad and specific terms to give candidates the option to share information about the phenomenon on a macro level without necessarily implicating themselves. I followed up each structured interview with a request to shadow the candidate for a few days on the campaign trail, and spent 14 days shadowing six candidates at various events. ${ }^{26}$

The secondary focus of my qualitative work is to illustrate the dynamics of criminal clientelism in voters' everyday lives. Many of the interviews with community leaders, and even candidates or staffers who are familiar with life amongst criminal groups, shed light on this dynamic. I also obtained access to anonymous complaint data about electoral irregularities from the TRE-RJ, such as vote buying, illegal advertising, and abuse of public office. Transcripts of select complaints about organized crime demonstrate the extent to which criminal group leaders corral and gatekeep in their communities.

\section{Data}

I use two sub-municipal sources of data to analyze voting behavior in criminally dominated favelas in the Rio de Janeiro city council elections of 2008, 2012, 2016, and 2020. First, I construct an original panel database mapping the territorial boundaries of criminal governance in the city, identifying all favelas that are under criminal control, using information scraped from local crime blogs. Second, I use official ballot-box-level electoral returns to measure my three outcome variables related to turnout, voting in blocs, and the number of candidates that receive votes.

\footnotetext{
${ }^{26}$ Though I asked every candidate I interviewed to shadow them, only six followed up to confirm the offer. I attended campaign events in favelas and non-favelas, and spent valuable time talking to staffers about how they managed campaigns.
} 


\subsection{Explanatory Variable: Criminal Governance}

I constructed a new dataset on the presence of organized crime in Rio de Janeiro's 1,018 favelas from January 2015- January 2020. I began by defining the geographic boundaries of the city's favelas, obtained from the Pereira Passos Institute's (IPP) annual registry of favelas. Every year, IPP (a municipal city planning and data collection agency) calculates the favela boundaries using satellite imagery; it adds new informal settlements to the city's registry and alters the boundaries of existing favelas. Most favelas' territorial boundaries are stable year to year because of pre-existing geographic constraints (e.g., they are built on hills and buttress the existing development on the flat land). I hand coded a list of alternative identifiers for each favela on this list.

I scraped the anonymous blog Crimes News $R J$ to identify which criminal groups were present in which favelas over time. ${ }^{27}$ The blog reports on criminal warfare in the city and reveals the governing criminal faction in most favelas. ${ }^{28}$ I used string processing to match the blog text with each favela name and its criminal leader to the geolocated favela name from IPP, described in greater detail in Appendix A2. I code a favela as being governed by a certain group if its name appears in the blog followed by the faction's name in parentheses, a common heuristic used by the blog author (see Figure A3 for an example).

My criminal governance variable takes one of five values: one of the three drug trafficking organizations, 1) ADA, 2) CV, 3) TCP, 4) the extortion racket milicias, or 5) no data, for favelas that were not mentioned in any of the blog posts. Across the panel, I was able to assign a criminal group leader to $64 \%$ of favelas in the city that cover $85 \%$ of the favela population. Figure 5 shows a cross-section of the database. The majority of the favelas for which I have no data for are very small informal settlements with a mean population size of 598 per favela (compared to 1,860 for criminally governed favelas). ${ }^{29}$ Though a lack of data is not a guarantee that criminal groups are absent from these communities, the demographics

\footnotetext{
${ }^{27} \mathrm{I}$ am not the first person to try to systematically measure criminal dominance in Rio de Janeiro. Anthropologists (Zaluar 2007) paved the way, painstakingly collecting this data at specific cross-sections, sometimes by visiting each favela in person to correctly identify which faction it belongs to. More recently, the data journalism organization Fogo Cruzado has published a 2019 cross-section, and Magaloni, Franco-Vivanco, et al. (2020) published a time series of dominance focused on favelas that were a part of the UPP public security program, both drawing from Disque Denuncia anonoymous help line tips. Mine is the only dataset I know of that is draws from these blog reports and indicates changes in turnover when favelas are taken over by rival factions.

${ }^{28}$ The blog author is anonymous yet credible. I learned about the blog from members of the State Ministry of Public Security, which confirmed that the criminal governance patterns it identifies very closely mirror their intelligence information.

${ }^{29}$ SABREN, the Low Income Settlements System, tabulates favela population estimates and shares them with IPP.
} 
Figure 5: Criminal Governance in Rio de Janeiro's Favelas
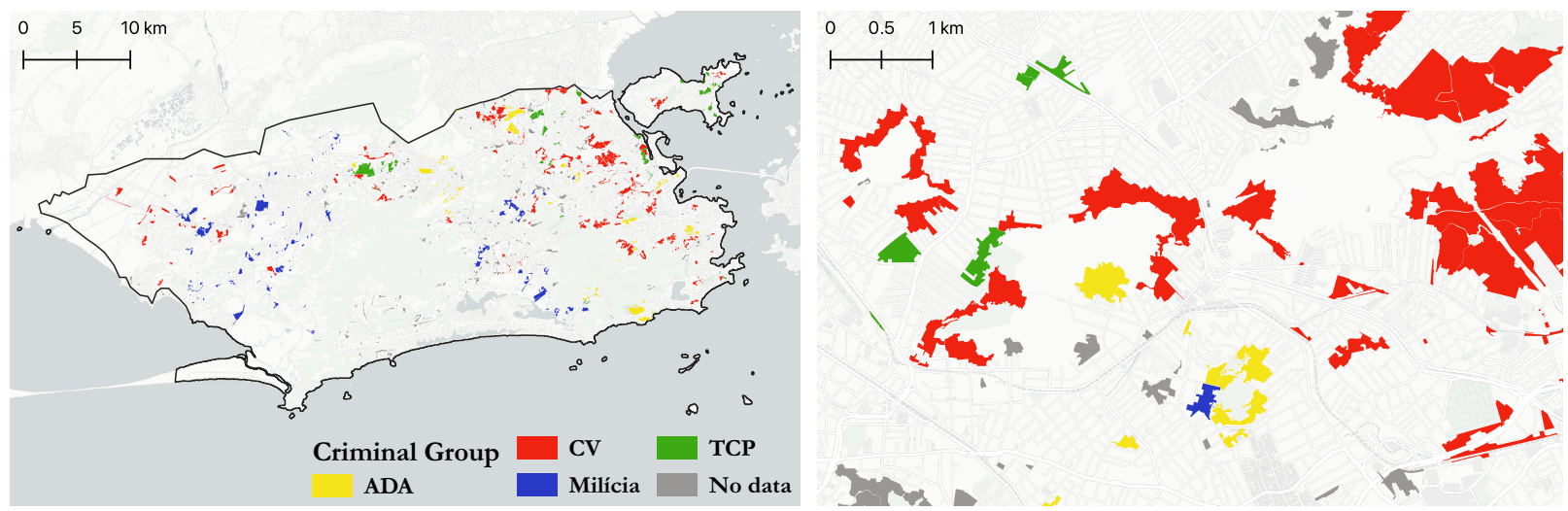

Note: The map in the left panel shows the entire city of Rio de Janeiro with favelas colored according to the governing criminal group in October 2016. The right panel displays a zoomed-in section of the North Zone of the city where several different criminal groups govern favelas. I use an OpenStreetMap base map in both figures. Source: author's elaboration and IPP.

indicate that the "no data" favelas tend to be much smaller clusters of poor voters spread throughout the city, making them less pivotal electorally and less strategically important for criminal groups that benefit from controlling residents.

Table 1 shows the distribution of favelas by criminal group at the October 2016 crosssection immediately before the municipal elections and the first election year in my database. My data reveals that many more favelas are dominated by criminal groups (in both absolute number and population size) than those that are potentially undominated in the "no data" category. Unless otherwise specified, the following analyses use the sample of 654 favelas coded as dominated by one of the four criminal groups.

This list of 654 criminally dominated favelas (in which 1.2 million voters live) comprises the population of interest for my primary empirical strategy. For every ballot box in which a favela resident in this sample votes, I obtained the proportion of voters that live in any one favela. I represent this proportion with the ShareFavela variable in Equation 1, which is coded $0-1$.

\subsection{Electoral Outcome Variables}

I use ballot-box-level returns data from the Supreme Electoral Tribunal (TSE) to calculate three electoral outcomes, one for each of my three hypotheses: 1) turnout, 2) vote concentration, and 3) the number of candidates receiving votes. These variables are indicators of corralling, aggregate ballot-box-level competition, and gatekeeping, respectively. Figure 6 
Table 1: Favela Distribution by Criminal Group

\begin{tabular}{lcc} 
& \multicolumn{2}{c}{ Total Number in Rio de Janeiro: } \\
\cline { 2 - 3 } Faction & Favelas & Favela Voters \\
\hline ADA & $101(9.9 \%)$ & $232,455(16.2 \%)$ \\
CV & $314(30.8 \%)$ & $574,703(40.0 \%)$ \\
TCP & $74(7.3 \%)$ & $185,876(13.0 \%)$ \\
Milícia & $165(16.2 \%)$ & $224,022(15.6 \%)$ \\
No data & $364(35.8 \%)$ & $217,916(15.2 \%)$ \\
\hline Total & 1018 & $1,434,975$
\end{tabular}

Note: This is the distribution of favelas, and favela voters, according to the governing criminal group in October 2016. Source: author's calculation.

illustrates kernel density plots of each outcome variable's distribution.

The first outcome, turnout, is an indicator of voter corralling. Voting is mandatory in Brazil, and though compliance is imperfect, turnout is high (approximately $80 \%$ in recent elections, shown in the top panel of Figure 6). This makes Brazil a particularly rigorous case in which to test the corralling hypothesis; other studies on broad voting behavior (Cox 2015; Cox et al. 2020) and turnout in clientelistic contexts (Gans-Morse et al. 2014; Nichter 2008) acknowledge that there is less variation in turnout where voting is compulsory. I calculate turnout for each ballot box by dividing the number of registered voters by the total ballots cast.

The second outcome, vote concentration, is the summary indicator of bloc voting for the same top candidate or candidates. I operationalize this variable using the HerfindahlHirschman (HHI) monopoly competition index, a common measure of concentration that has been used in studies of electoral competition in the political science and economics literatures (Gottlieb and Kosec 2019; Fujiwara and Wantchekon 2013; Crisp and Ingall 2002). For every ballot box $b$, I construct the HHI by summing the share of votes received $\left(v_{c}\right)$ of all candidates $c \in\{1, \ldots n\}$ who ran for city council in a given year:

$$
H H I_{b}=\sum_{c=1}^{n} v_{c}^{2}
$$


Figure 6: Density Plots of Outcome Variables
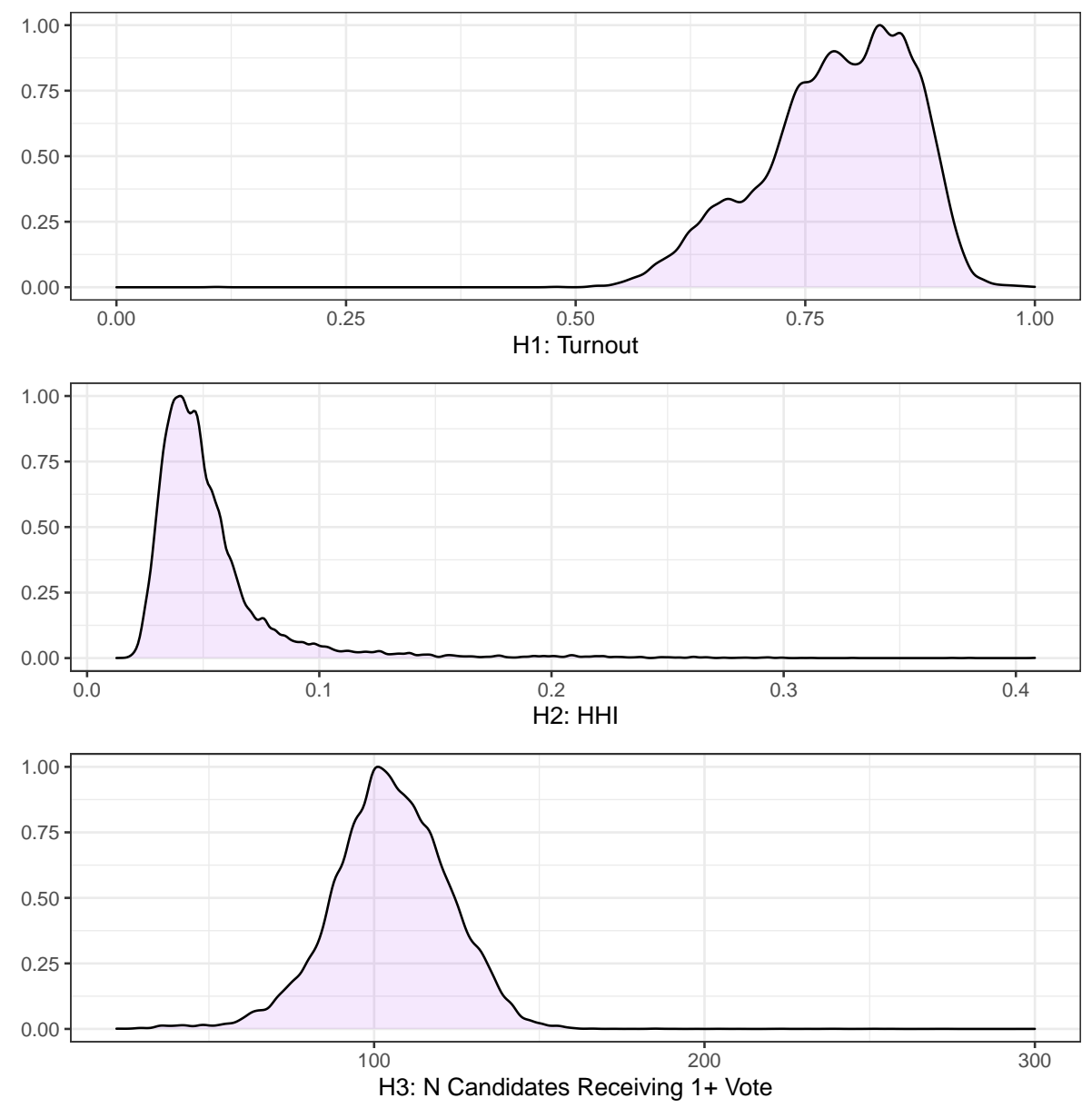

Note: These kernel density plots include all observations from all four election years I analyze: 2008, 2012, 2016, and 2020. When broken down by year, the distributions change little. Source: TSE.

Since all values of $v$ are vote shares between 0 and $1, H H I_{b}$ is coded from $0-1$. $H H I_{b}$ takes a maximum value of 1 if one candidate receives $100 \%$ of the votes in a ballot box. $H H I_{b}$ decreases as the vote share grows more evenly distributed across a wider range of candidates. Given the vast number of candidates who run in Rio de Janeiro's elections, many receive zero votes in a given ballot box.

The third outcome, the number of candidates receiving votes, is an indicator of candidate gatekeeping. If criminal influence over the candidate pool decreases voter access to potential candidates, it follows that ballot boxes with a higher proportion of favela voters should register votes for fewer unique candidates. Though this does not represent a change in the underlying candidate pool, my hypothesis suggests that we will observe criminal groups pruning the effective candidate pool in their communities by restricting candidate access to 
voters. I operationalize this hypothesis by summing the number of candidates that receive at least one vote per ballot box.

\section{Results}

I examine how residents of criminally dominated favelas vote, identified through my criminal dominance database. Section 6.1 considers how criminally governed residents vote as a crosssection, and Section 6.2 over time. The unit of analysis for all models shown is the ballot box, where approximately 300-500 individuals vote. I focus on city council races in municipal elections in the city of Rio de Janeiro in 2008, 2012, ${ }^{30} 2016$, and 2020.

\subsection{Exogenous Ballot Box Assignment}

The main results, reported in Table 2, correspond to the natural experiment described in Section 4.1. All models analyze how an increase in the share of favela residents at the ballot box (ShareFavela) impacts one of three outcome variables that map onto my core hypotheses: 1) turnout, 2) HHI concentration index, and 3) the number of candidates receiving votes. All three models tell a story that is consistent with my hypotheses: a one-standarddeviation increase in the share of favela voters (a 10\% rise) at a ballot box corresponds to higher turnout, a more concentrated vote share, and fewer candidates receiving votes. When aggregating across ballot boxes, blocs of mobilized favela voters represent tens of thousands of votes - enough to make or break an election for dozens of candidates. The inclusion of yearly, favela, and polling-station-level fixed effects provides substantial evidence that this difference in voting behavior exists over time (four election cycles over 12 years) and is not idiosyncratic to a specific criminally dominated area or region of the city.

Column 1 illustrates that turnout increases with the share of favela residents per ballot box. A one-standard-deviation increase in the share of favela voters per ballot box is associated with an increase in turnout of 0.0027. In an average-sized polling location with 4,000 registered voters, 600 of whom live in a favela, we would expect 10.8 more people to turn out than in a similar sized polling location that has just 200 favela residents. In a similarly sized polling place where half of the residents live in the favela, we would expect an additional 64.8 voters to turn out. This effect is modest yet robust, especially considering the expectation for low variation in turnout in a context where voting is mandatory (Gans-Morse et al.

\footnotetext{
${ }^{30}$ For analyses focusing on the election years of 2008 and 2012, which predate my database, I use the 2016 faction assignment.
} 
Table 2: Effect of Residency in Criminally Dominated Favela on Voting

\begin{tabular}{lccc}
\hline \hline & \multicolumn{3}{c}{ Dependent variable: } \\
\cline { 2 - 4 } & H1: Turnout & H2: HHI & H3: N Candidates \\
& $(1)$ & $(2)$ & $(3)$ \\
\hline ShareFavela & $0.0027^{* *}$ & $0.0002^{* *}$ & $-0.2148^{*}$ \\
& $(0.0007)$ & $(0.00006)$ & $(0.0681)$ \\
\hline Favela FE & & & $\checkmark$ \\
Polling Station FE & $\checkmark$ & $\checkmark$ & $\checkmark$ \\
Yearly FE & $\checkmark$ & $\checkmark$ & $\checkmark$ \\
Observations & 260,085 & 260,085 & 260,085 \\
R $^{2}$ & 0.222 & 0.611 & 0.524 \\
\hline \hline
\end{tabular}

Note: Estimates of Equation 1 are shown for the three primary voting outcomes in ballot boxes for city council-level elections in Rio de Janeiro. The ShareFavela regressor is standardized. I include favela, polling station, and yearly fixed effects and pool the regression across four election years: 2008, 2012, 2016, and 2020. Standard errors are clustered at the level of randomization, the polling station-year level. ${ }^{*} \mathrm{p}<0.1 ;{ }^{* *} \mathrm{p}<0.05 ;{ }^{* * *} \mathrm{p}<0.01$

2014). Recalling from Section 3.1 that nearly half of the city council seats were decided by a margin of 1,000 votes or less during the study period, it makes sense that marginal candidates would be interested in criminal brokers' corralling services that increase turnout in addition to flipping undecided or opposition voters.

Column 2 of Table 2 shows that the vote is more concentrated for top candidates (because there is less competition) as the share of favela residents increases across ballot boxes. A one-standard-deviation increase in the share of favela voters corresponds to an increase in vote concentration of 0.0002 . This would be equivalent to a leading candidate passing from capturing $20 \%$ of the vote share to $25 \%$ of the vote share while all other candidates capture $12 \%$ or less of the vote. ${ }^{31}$ When we again consider the average-sized polling station with 4,000 voters, a one-standard-deviation increase in the share of favela voters means that the leading candidate moves from capturing 800 to 1,000 votes - possibly enough to win. Both corralling and gatekeeping could contribute to an increase in vote concentration.

Lastly, Column 3 shows that the number of city council candidates to receive at least one

\footnotetext{
${ }^{31}$ In this example, let us say our initial vote concentration is $H H I=0.107$, where the winning candidate receives 0.2 of the vote share and in descending order, three candidates receive $10 \%$ of the vote share, five obtain $8 \%$, and two receive $5 \%$ of the vote share. As the leading candidate wins a larger share of the vote moving from $20 \%$ to $25 \%$ and $H H I=0.1072$, the second-place candidate collects $12 \%$ of the vote share, 12 candidates receive $5 \%$, and three candidates receive only $1 \%$ of the vote share.
} 
vote decreases as the share of favela voters per ballot box falls. A one-standard-deviation increase in the share of favela residents corresponds to 0.215 fewer candidates winning at least one vote, which supports the argument that criminal groups prune the candidate pool by gatekeeping. As the share of favela residents increases within a ballot box, the number of candidates the voters choose decreases. For example, a ballot box with $85 \%$ favela voters will register votes for one less candidate than a ballot box with $45 \%$ favela voters, and two fewer candidates than a ballot box with $5 \%$ favela voters.

As in every natural experiment, there is the risk that pre-treatment confounders, such as criminal group, may be driving the results. To minimize concerns about such observed potential confounders, I plot point estimates for my three outcomes of interest in Figure 7, reporting my preferred specification alongside additional ones. Model 1 in all three panels corresponds to the point estimates shown in Table 2. For each outcome variable, I report four additional analyses, each of which addresses a different concern about confounders or model specification.

One such concern might be that only a subset of communities governed by criminal groups are driving the result. To address the possibility that the use of criminal clientelism varies between criminal groups, Model 2 in all panels of Figure 7 reports coefficients that control for the criminal faction that dominates a given group of favela voters (Table A2). It is also possible that the faction itself is not as important as its governing style, which influences how they interact with other state actors, such as the police (Magaloni, FrancoVivanco, et al. 2020). I address this concern by controlling for criminal business type, comparing milícia-dominated to all drug-trafficking-dominated territory in Model 3 (Table A3). Another possibility might be that criminal groups exert strong influence over the polling stations at the boundary of their favela, but this influence wanes as the polling place moves farther into non-criminally dominated territory. Model 4 shows that this is not the case by controlling for polling places' distance to the favela boundary (Table A4).

It is also possible that this effect is driven by voters' reactions to organized crime. The presence of criminal groups may dissuade voters from voting for a viable candidate, perhaps due to disillusionment with the candidates in their neighborhood. Once inside the private voting booth, voters may spoil their ballot or vote blank as a protest vote, voting in bloc for nobody and pushing down the number of candidates that receive a vote. If this were the case, we may expect the proportion of spoiled ballots to be correlated with the outcomes measuring vote concentration and the number of candidates receiving votes $(\mathbf{H} \mathbf{2}$ and $\mathbf{H 3})$, but not necessarily with turnout. However, controlling for the proportion of spoiled ballots 
Figure 7: Models of effect of residency in criminally dominated favela on voting
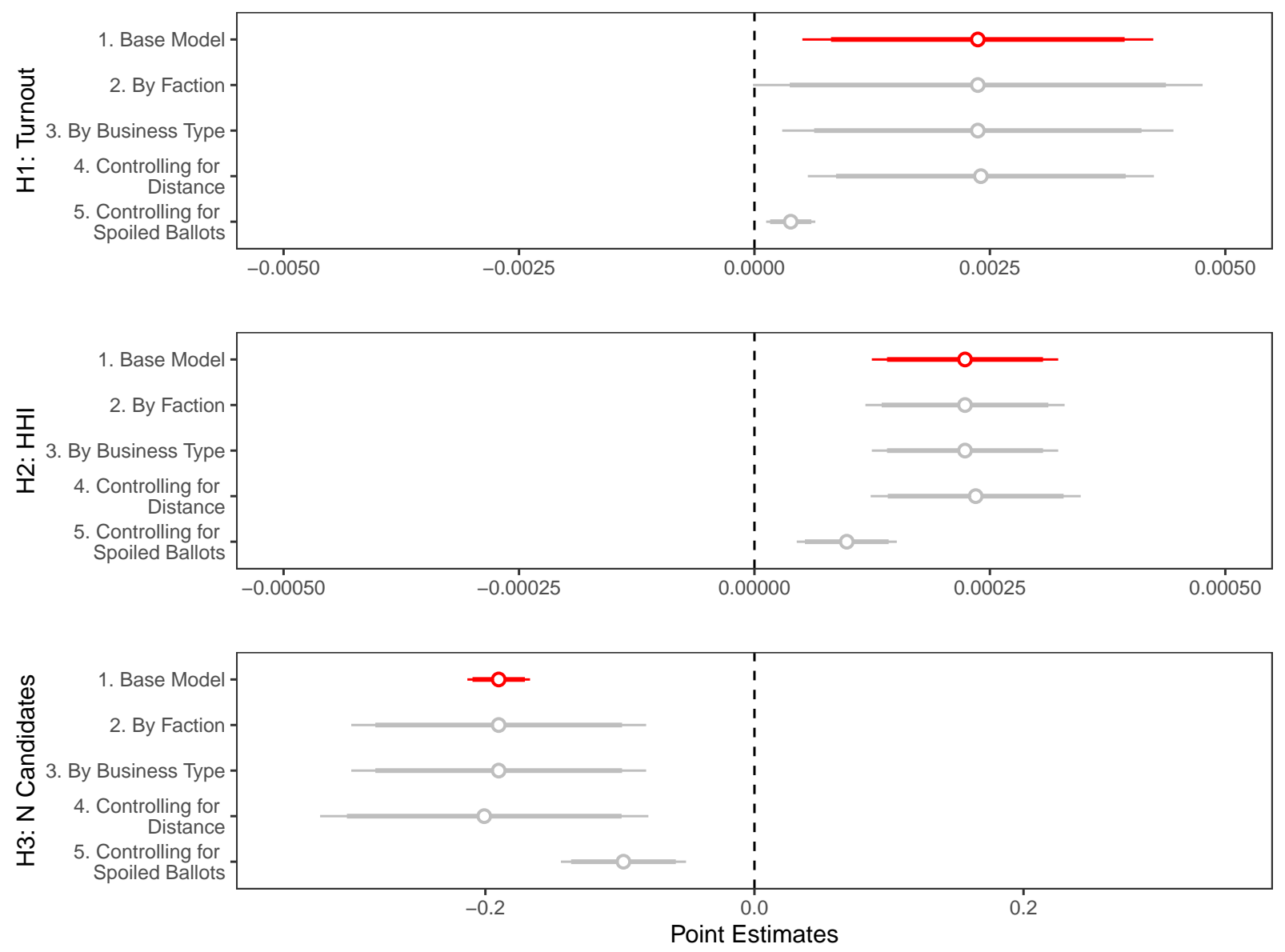

Note: Each of the 15 models shown here corresponds to Equation 1. The outcome of interest in the top panel is turnout, HHI in the middle panel, and the number of candidates receiving votes in the bottom panel. Model 1 shows the results from the main specification reported in Table 2, and regressions for all other models including relevant control variables or subsets of the data and reported in Appendix A3.

for all three outcomes does not change the effect size or significance of the results, as shown in model 5 and reported in Table A5. I also demonstrate that the share of spoiled ballots is uncorrelated with the three main outcomes, independent of the share of voters in the favela (Table A6).

\subsection{Changes in Criminal Governance Over Time}

I now leverage temporal variation in criminal governance to examine how changes in the stability of criminal rule affect voting over time, as described in Section 4.2. First, Figure 8 plots parallel time trends for favelas in the sample to examine the raw data. Panel A provides 
visual confirmation that HHI increased (the vote grew more concentrated) in communities that had a stable criminal ruler relative to communities that were caught in the middle of a power scramble during the elections. Panels B and C, respectively, display slightly steeper decreases in candidates receiving votes and in turnout among treated favelas. The time trends broadly suggest that residents living under the governance of a clear criminal faction vote in bloc and for fewer candidates than voters exposed to a criminal power scramble, even after accounting for city-wide time trends.

Figure 8: Voting Trends in Stable and Contested Favelas, 2004-2016

A
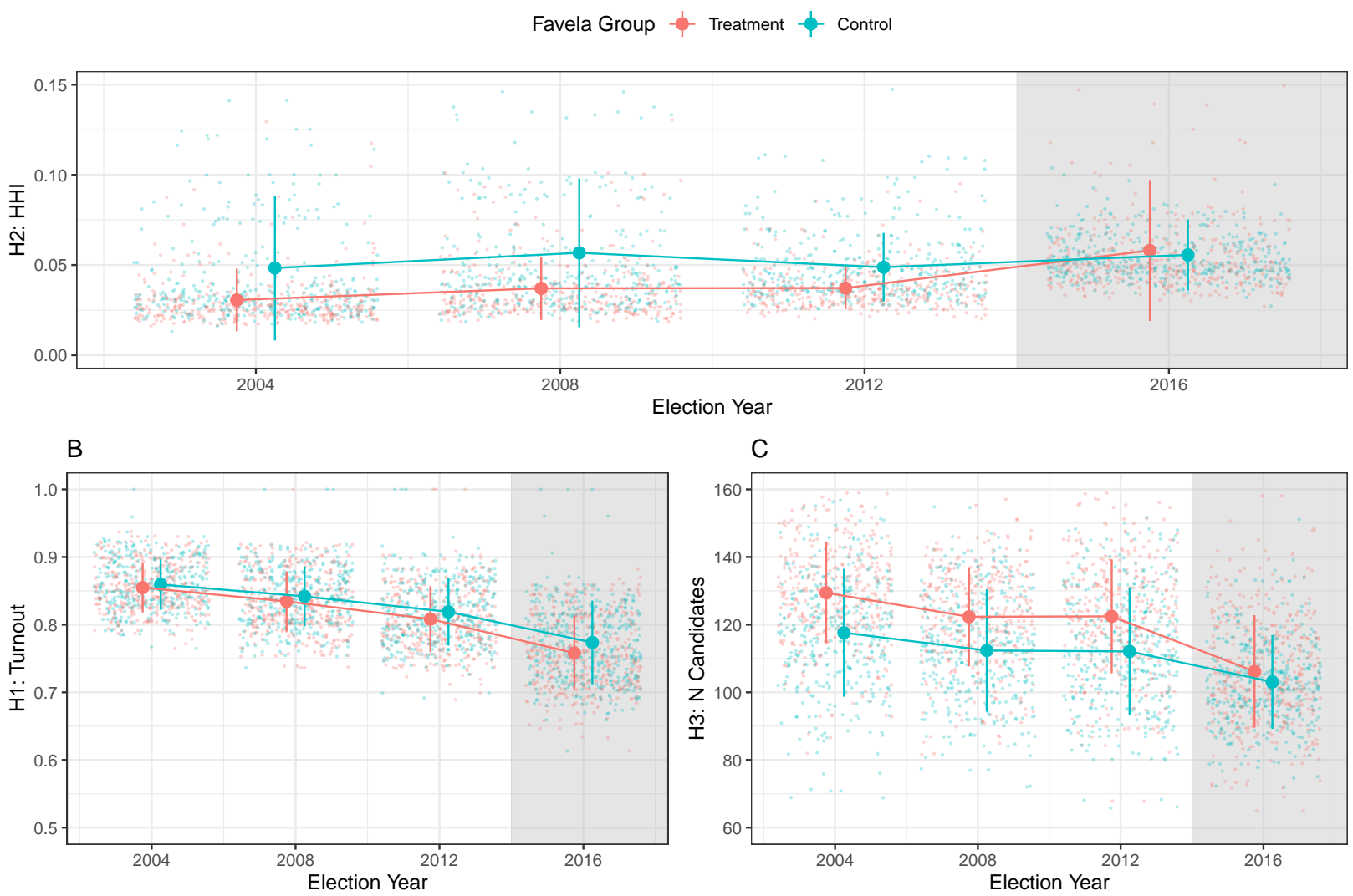

Note: Each panel shows one of three outcome variables for the two groups of favelas, stable governance (treatment) or contested (control). I plot unadjusted outcome variables for each ballot box-year for the two time periods considered in the difference-in-differences analysis, as well as two election years prior to better illustrate time trends. Points are jittered for each election year, and each sample mean is plotted with a

$95 \%$ confidence interval. Source: TSE.

The difference-in-differences estimator confirms that stable criminal governance is associated with bloc voting, but not with turnout. Column 1 of Table 3 shows that HHI is 0.016 higher among communities with stable criminal control in 2016, even after controlling for 
time trends and polling-station-level factors. Drawing from the example above in Footnote 31 , this increase in vote concentration could be the equivalent of a leading candidate moving from capturing $20 \%$ of the vote share to $30 \%$, while all other candidates capture $10 \%$ or fewer votes. $^{32}$ Column 3 shows that approximately seven fewer candidates received votes per ballot box in favelas that maintained steady criminal control than in those that did not. Lastly, the results on turnout are inclusive, shown in Column 2. This may be due to the countervailing effect of criminal power scrambles that could increase turnout in the control group, which Arjona (2017) calls an "awakening effect," or the countervailing effect of crime victimization on turnout that Córdova (2019) observes.

Table 3: Effect of Criminal Governance on Voting over Time

\begin{tabular}{lccc}
\hline \hline & \multicolumn{3}{c}{ Dependent variable: } \\
\cline { 2 - 4 } & H2: HHI & H1: Turnout & H3: N Candidates \\
& $(1)$ & $(2)$ & $(3)$ \\
\hline Stable $\times 2016$ & $0.016^{* * *}$ & 0.029 & $-7.275^{* * *}$ \\
& $(0.002)$ & $(0.027)$ & $(1.211)$ \\
& & & $-9.867^{* * *}$ \\
& $0.007^{* * *}$ & -0.023 & $(0.775)$ \\
& $(0.001)$ & $(0.026)$ & $-2.592^{* *}$ \\
Stable & $0.008^{* * *}$ & -0.009 & $(1.139)$ \\
& $(0.002)$ & $(0.019)$ & $-1.250^{* *}$ \\
ShareFavela & 0.0002 & 0.015 & $(0.513)$ \\
& $(0.0005)$ & $(0.010)$ & 1,397 \\
& & & 0.554 \\
Observations & 1,397 & 1,397 & 0.520 \\
$\mathrm{R}^{2}$ & 0.522 & 0.391 & ${ }^{*} \mathrm{p}<0.1 ;{ }^{* *} \mathrm{p}<0.05 ;{ }^{* * *} \mathrm{p}<0.01$ \\
Adjusted $\mathrm{R}^{2}$ & 0.485 & 0.345 &
\end{tabular}

Why would favela residents with a stable criminal leadership vote in bloc more than those

\footnotetext{
${ }^{32}$ Assume the same initial distribution of votes as above, where $H H I=0.107$ and the winning candidate receives 0.2 of the vote share, three candidates obtain $10 \%$ of the vote share, five receive $8 \%$, and two obtain $5 \%$ of the vote share. An increase of 0.016 to $H H I=0.123$ would be the equivalent of the leading candidate capturing $30 \%$ of the vote share, the second-place candidate getting $10 \%$ of the vote, and nine candidates trailing with $5 \%$.
} 
that live in contested favelas? In a favela where a criminal group has consolidated power, the group may realize that election seasons are a time when its territorial control over voters can be further monetized by corralling and gatekeeping. However, in favelas involved in leadership scuffles, the criminal group may be focusing more of its energy on gatekeeping criminal rivals than on collecting a few extra dollars by striking deals with politicians. The downstream implications of criminal leadership struggles include a more disorganized climate and the rupturing of ties between residents and prospective candidates, those trying to either forge a path into the favela or to maintain relationships with former contacts.

I further test the logic that stable criminal governance better explains bloc voting than other favela-level factors by analyzing voting patterns when the state reincorporates favelas. In Appendix A2.3, I estimate the same model and explain the design in greater detail, comparing ballot boxes across four favelas - two that were raided by the police before and two after the 2016 elections - that were part of Rio de Janeiro's UPP (Police Pacifying Units) program, which was designed to expel organized crime from favelas and reincorporate them under state governance (Magaloni, Franco-Vivanco, et al. 2020). The electoral returns in favelas with intact criminal governance during the 2016 election were more concentrated across fewer candidates than in favelas in which criminal governance was upended (Table A1). These results provide further supporting evidence that it is not simply a "favela residency" effect driving the low levels of competition at the ballot box.

\subsection{Robustness}

I further explore the robustness of the cross-sectional results through a closer analysis of different subsets of the data and alternative measures of the dependent variable. I first separate the pooled regressions from Table 2 to show the results for each of the four election cycles in Table A7. Across the entire 12-year period, despite changes in the political and criminal landscape, the point estimates remain similar for each outcome of interest. Moreover, even considering only ballot boxes in polling stations that buttress the favela boundary (those within a 100 meter radius of the favela borders which only correspond to the treatement group in Hidalgo and Lessing (2015)), I find that voting outcomes can still be explained by the share of favela residents in a ballot box (Table A8).

I conduct sensitivity tests of my dependent variables. I consider an alternative to the HHI to measure vote concentration that calculates the share of votes that the top five vote earners receive as a proportion of total votes per ballot box. I report all regressions estimated in Panel 2 of Figure 7 in Table A9. The effect size changes little. Tables A10 and A11 show 
that results are robust when operationalizing the third outcome variable as the number of candidates that receive at least two or at least five votes per polling station, respectively.

\section{Qualitative Evidence}

I support my quantitative results with two types of evidence that further interrogate the corralling and gatekeeping mechanisms. The quantitative results in the above section alone cannot explain why voters turn out in higher numbers or why they choose the same candidate. If my results hold, then we should observe candidates and criminal group leaders acknowledging that deal-making occurs (if responding truthfully), and citizens recognizing that candidates bribing criminal groups to corral and gatekeep in their communities. I draw on anonymous complaints to the electoral authority from voters to illustrate the micro-logic of how corralling and gatekeeping shape electoral outcomes. I draw on candidate and voter interviews throughout to demonstrate that candidates hire criminal groups to increase their chances of winning elections. This section provides supporting evidence that politicians hire criminal groups to corral and gatekeep, from both the voters' and the candidates' point of view.

\subsection{Criminal Clientelism from the Politicians' Point of View}

Criminal clientelism affects all candidates. Even if candidates are not striking deals with criminal groups, gatekeeping impedes their ability to enter and campaign in certain communities where they may have otherwise, absent criminal-politician bargains. In my 37 structured interviews with candidates, every single candidate acknowledged that criminal clientelism was a widespread phenomenon among candidates for legislative office. Even candidates who claimed to never have bribed a criminal group had a deep understanding of what deal-making with criminal groups entailed, some with theories about the types of candidates most likely to use criminal clientelism as an electoral strategy or the relative efficiency of criminal clientelism vis-à-vis other strategies.

Candidates acknowledge that corralling can convince residents to vote for them. A common sentiment among candidates was that they were very unsure how effective any of their campaign tactics were at persuading voters, and criminal clientelism lowered their uncertainty. One campaign manager (who was vehemently against paying criminal organizations) admitted that he had no idea what convinced voters and what did not, so his plan was 
to "continue doing everything every day until the election." 33 A campaign manager (who struck deals with criminal groups on behalf of his boss) echoed that sentiment about other campaign strategies, claiming that lower uncertainty was part of what makes criminal clientelism appealing. This candidate said that "you can count on having those votes" 34 after striking the group-level deal with a criminal group, but the same assurance was not true for other strategies, even other vote-buying strategies. Candidates were more inclined to talk about corralling as a persuasive act rather than a coercive act; eight candidates mentioned how criminal groups pass along benefits or coordinate campaign events for voters as part of the agreement. One staffer who opened up about coercion admitted that the vote yield was especially high when criminal groups used violence during the campaign period. ${ }^{35}$

Candidates and staffers acknowledge that gatekeeping can further increase their chances of collecting many votes in a criminally dominated area. Of the candidates who admitted to colluding with criminal groups, most described gatekeeping as if it were part of the deal or an added benefit, but not the core component. Four different candidates referred to gatekeeping using an idiom that means "closing a deal with a specific person," 36 indicating that an explicit part of the deal was the exclusive access that gatekeeping conferred. Many candidates that used criminal clientelism had a high degree of confidence that they would be the only ones campaigning in the communities they bought access to. When asked why criminal groups would respect the deal and not accept bribes from every candidate, one bribe-paying candidate responded, "If I win, I'll send the cops in and destroy their business. They know not to violate the deal." 37 Candidates also experienced the receiving end of gatekeeping. Twelve candidates recounted experiences of being told they could not campaign somewhere or being asked to leave in favelas where they did not have prior arrangements with the criminal leaders.

\subsection{Criminal Clientelism from the Voters' Point of View}

Residents of criminally-governed areas recognize that politicians hire criminal groups to help with their campaigns. In my 14 interviews with favela residents and community leaders, every one of them expressed some degree of awareness of the deal-striking that occurred between criminals and politicians in their community. Some residents connected to neighborhood

\footnotetext{
${ }^{33}$ Author's interview, Campaign manager 2, September 2018.

${ }^{34}$ Author's interview, Campaign manager 3, August 2019.

${ }^{35}$ Author's interview, Staffer 2, July 2018.

${ }^{36}$ In Portuguese, fechar com (alguem)

${ }^{37}$ Author's interview, Candidate 3, December 2019.
} 
politics or friends with the criminal group members knew dollar amounts that were traded, others further removed still knew about the existence of some sort of electoral exchange. This is also reflected in the anonymous complaints to the electoral authority. One complainant to the electoral authority writes, "CANDIDATE literally bought the drug traffickers and the presidents of the local neighborhood associations." This lament was echoed by my interview respondents, who said, "If candidates don't pay, they can't enter" 38 and "The traffickers in this community always strike a deal with somebody... usually whoever pays the most." 39

If corralling is occurring, we would expect to see criminal groups deliver votes through group-level mobilization for the candidate they struck a deal with. Several voters highlight through their complaints to the electoral authority how criminal groups use the group-level influence to extend their territorial control to vote choice. One complainant explains that terror has spread throughout the community, stating, "The candidate is allied with the traffickers in REGION. They have signs and banners in their name, and community members are forced to hang signs up and publicly declare their support or suffer the consequences..." Another notes that a milícia member is "circulating the neighborhood in a white Chevrolet Onix, threatening voters." Yet another explains how the criminal group's control extends beyond the use of force, stating, "CANDIDATE bought the support of the milicias in LOCATION. They're using the neighborhood association to distribute food for CANDIDATE." A different complaint mentions the group-level fear that milícias provoke on election day, noting that they were "splitting up at different polling places and staying there all day on the street to ensure that the population goes to vote for their candidate."

Voters notice when criminal groups attempt to corral them - both through the use of coercion and persuasion. The most effective criminal brokers will not only corral voters to turn out, but to vote for their particular candidate. In Rio, voters have complained about corralling that uses coercive tactics, stating, "Traffickers from FACTION are threatening that if CANDIDATE doesn't do well in the polls, the community will suffer retaliation." Voters have also complained about corralling rooted in persuasive tactics, reporting, "This candidate is offering parcels of land with the support of the local traffickers today until 5pm. She has the help of a woman named NAME for the distribution of the land. The land was invaded by traffickers and now, in support of CANDIDATE, they are distributing the land in exchange for votes, demanding that the voter take a photo inside the voting booth in order to claim their lot." Recall that when corralling, criminal groups may use coercion and

\footnotetext{
${ }^{38}$ Author's interview, Favela resident 1, June 2017.

${ }^{39}$ Author's interview, favela residents 2-4, July 2018.
} 
persuasion together, the two are not mutually exclusive. Complainants note criminal groups' dual use of coercion and persuasion when corralling, noting, "CANDIDATE, in addition to offering money to buy votes, threatens residents that if he discovers that they did not vote, they will suffer the consequences. CANDIDATE is involved with the milicia."

If gatekeeping is occurring, we would expect criminal groups - after they close a deal with their preferred candidate - to prohibit other candidates from entering the neighborhood and accessing voters. Since voters only have access to the criminal group's preferred candidate, this should reduce the number of outside options voters select on election day and further concentrate the vote around the criminal group's chosen candidate, as shown in Section 6. The anonymous complaints suggest that criminal groups' gatekeeping strategies are driving the results, pruning outside candidates from the voters' candidate pool and restricting access to their chosen candidate only. One complainant confirms thatcandidates are either denied or granted access to favelas in Rio de Janeiro, explaining, "Here in FAVELA, they are not letting any other candidate that is not CANDIDATE work here. He made a deal with the local traffickers, other candidates that want to work here have to pay 15 to 20 thousand reais... People that want to work in the neighborhood for another candidate can't if they don't pay the traffickers."

Some voters appear to be aware, on a macro level, of how gatekeeping in their community affects other candidates' access to voters and shapes information about candidates. Once the criminal group has tilted the playing field in favor of its preferred candidate, voters receive a lot of information about that candidate and little about those that are not allowed in. A voter shares how this preferential granting of access to candidates prevents voters from exposure to other candidates and learning about them, stating, "It seems like we're living in another world, cars with other candidate's decals are publicized and prohibited from moving about NEIGHBORHOOD. CANDIDATES A and B struck a deal with the traffickers from NEIGHBORHOOD, buying the entire community, prohibiting posters, decals, pamphlets, and even activity involving other candidates on residents' social media. Democracy doesn't exist in Rio de Janeiro."

Finally, corralling and gatekeeping are not necessarily mutually exclusive. The two acts reinforce each other; when gatekeeping reduces the number of candidates that can access voters, it facilitates election-day corralling for the criminal group's preferred candidate. Multiple complainants note how the two can be used in tambem. One voter writes, "The majority of the residents of NEIGHBORHOOD are being threatened by the local head trafficker, CRIMINAL A, who received $\mathrm{R} \$ 60,000$, to force the residents from there to vote for CANDIDATE 
B. It seems like last week they prohibited CANDIDATE B from entering any homes... also, it's not allowed to have any other form of campaign propaganda inside your house that's not for CANDIDATE A. According to stories, CRIMINAL made it clear that if he discovered who didn't vote for CANDIDATE A, you'd be killed." Another notes, "Today when I went to vote, I was coerced by milícias to vote for CANDIDATE. Surrounding the polling station there were lots of flyers and stickers for him, at the entrance there were many spread over the floor. He was the only one who came to campaign in my neighborhood (a milicia-dominated area), and lots of milícia members were distributing pamphlets for him. A few days ago his carro de som (car with stereo attachment) was driving inside the neighborhood for days on end."

\section{Conclusion}

Politicians all over the world call on criminal groups' help to win elections. As specialists in violence and purveyors of order, criminal groups that govern have a high degree of influence and control over voters, which candidates seek. This paper argues that politicians sometimes employ an electoral strategy I call criminal clientelism, a strategic interaction between politicians and criminal groups in which votes are traded to influence elections. Criminal groups, when hired as brokers, deliver votes by corralling voters and gatekeeping rival candidates. I offer empirical evidence of both corralling and gatekeeping, showing that voters are more likely to turn out (and vote in bloc) in criminally governed territory. This paper also demonstrates that the mere presence of criminal groups is not enough to deliver votes in bloc to a candidate. Successful corralling and gatekeeping require the criminal group to govern, maintaining order and influence throughout the community.

My paper reveals how criminal groups derive power from territorial control and their role as governance provider - and use it to corral and gatekeep. Past research has argued that criminal groups that want to influence electoral outcomes strategically use violence or bribes to sway voters (Albarracín 2018) or intimidate or assassinate rival candidates (Trejo and Ley 2019; Dell 2015). But this is only part of the story. I demonstrate that criminal groups rely on their group-level influence as governance providers to influence electoral outcomes by corralling. The group-level threats and rewards that criminal groups issue to voters effectively elicit high compliance because of the criminal group's role as the purveyor (or destroyer) or order in the neighborhood. I also demonstrate that criminal groups leverage their control over territory to gatekeep, restricting access to voters to only their chosen 
candidates. By impeding access for candidates who do not pay up, gatekeeping influences which candidates voters have information about, making it more challenging for voters to learn about candidates not allied with criminal groups, effectively pruning the local candidate pool. Future research should investigate how these mechanisms shape which politicians are more likely to pursue criminal clientelism as an electoral strategy.

Rio de Janeiro is a microcosm in which we can observe criminal governance, order and disorder in criminal conflict, and candidate competition at the sub-municipal level, but that does not mean the arguments are restricted to the above scope conditions. While this paper focuses on the dynamics among candidates, criminal groups, and voters at the local level, the argument can be generalized to other electoral contexts where criminal groups govern voters. On the criminal side, I highlight the importance of governance provision, not just criminal presence alone. My argument applies to situations in which a criminal group maintains order over voters, even if it does not have competitors as close by as they do in Rio de Janeiro. The importance of governance provision explains why we observe criminal clientelism in Colombia (Acemoglu et al. 2013) and Sicily (Gambetta 1996) where the criminal group has stable control but no nearby competitors. It is also why we do not observe the phenomenon in areas rife with power scrambles where criminal groups never establish order.

This paper also contributes to a broader policy debate about fighting organized crime, the dominant approach to which overwhelmingly focuses on policing. Yet these strategies have mixed success and can often lead to physical or material harm to the voters who live amongst criminal groups (Magaloni, Franco-Vivanco, et al. 2020; Osorio 2015). Yet relying on the police as the dominant crime-fighting strategy seems one-dimensional, especially given the prevalence of symbiotic relationships between the state and organized crime (Barnes 2017). How can the government be expected to fight crime if individual policymakers - often those who write the rules - benefit from criminal connections?

When candidates can use criminal clientelism as an electoral strategy, it creates an agency dilemma in which politicians may want to weaken organized crime broadly, but not necessarily in the neighborhoods that vote for them. This tension makes it difficult to fight crime effectively and to get crime out of politics. My paper provides a theory that helps understand how much politicians can gain from partnering with criminal groups, and encourages skepticism about crime-fighting strategies that only focus on law enforcement instead of the broader governance challenges associated with criminal rule. To reduce criminal control over vulnerable voters, crime-fighting policy should go beyond policing and focus on providing governance and services for voters in criminally dominated neighborhoods. 
My conclusions inform our understanding of elections and democracy in contexts where criminal groups govern. When criminal groups wield such high levels of influence over voters, it is not surprising that enterprising politicians will be eager to capitalize on this influence at the ballot box. 


\section{References}

Acemoglu, Daron, James A. Robinson, and Rafael J. Santos (Jan. 2013). "THE MONOPOLY OF VIOLENCE: EVIDENCE FROM COLOMBIA". Journal of the European Economic Association 11, pp. 5-44.

Albarracín, Juan (June 2018). "Criminalized electoral politics in Brazilian urban peripheries". Crime, Law and Social Change 69.4, pp. 553-575.

Alesina, Alberto, Salvatore Piccolo, and Paolo Pinotti (Mar. 2019). "Organized Crime, Violence, and Politics". The Review of Economic Studies 86.2, pp. 457-499.

Ames, Barry (Jan. 2009). The Deadlock of Democracy in Brazil. University of Michigan Press.

Anderson, David M. (2002). "Vigilantes, Violence and the Politics of Public Order in Kenya". African Affairs 101.405, pp. 531-555.

Araújo, Vera and Chico Otávio (Sept. 2018). "Rio tem 300 currais eleitorais do tráfico ou milícia - Jornal O Globo". O Globo.

Arias, Enrique Desmond (2006). Drugs and Democracy in Rio de Janeiro: Trafficking, Social Networks, and Public Security. Chapel Hill: University of North Carolina Press.

- (2017). Criminal Enterprises and Governance in Latin America and the Caribbean. Cambridge: Cambridge University Press.

Arias, Enrique Desmond and Nicholas Barnes (2017). "Crime and plural orders in Rio de Janeiro, Brazil". Current Sociology 65.3, pp. 448-465.

Arjona, Ana (Sept. 2017). "Civilian Cooperation and Non-Cooperation with Non-State Armed Groups: The Centrality of Obedience and Resistance". Small Wars \& Insurgencies 28.4-5, pp. 755-778.

Auerbach, Adam Michael and Tariq Thachil (Nov. 2018). "How Clients Select Brokers: Competition and Choice in India's Slums". American Political Science Review 112.4, pp. 775791.

Auyero, Javier (Jan. 2001). Poor People's Politics: Peronist Survival Networks and the Legacy of Evita. Duke University Press Books.

Baldwin, Kate (2015). The Paradox of Traditional Chiefs in Democratic Africa. Cambridge Studies in Comparative Politics. Cambridge: Cambridge University Press.

Barnes, Nicholas (Dec. 2017). "Criminal Politics: An Integrated Approach to the Study of Organized Crime, Politics, and Violence". Perspectives on Politics 15.4, pp. 967-987.

Blattman, Christopher et al. (Feb. 2021). Gang rule: Understanding and Countering Criminal Governance. Tech. rep. w28458. National Bureau of Economic Research.

Blume, Laura Ross (Apr. 2017). "The Old Rules No Longer Apply: Explaining NarcoAssassinations of Mexican Politicians". Journal of Politics in Latin America 9.1, pp. 5990.

Bowles, Jeremy, Horacio Larreguy, and Shelley Liu (2020). "How Weakly Institutionalized Parties Monitor Brokers in Developing Democracies: Evidence from Postconflict Liberia". American Journal of Political Science 64.4, pp. 952-967.

Camp, Edwin (July 2017). "Cultivating Effective Brokers: A Party Leader's Dilemma". British Journal of Political Science 47.3, pp. 521-543. 
Cano, Ignacio and Thais Duarte (2012). No sapatinho: a evolução das milícias no Rio de Janeiro (2008-2011). Rio de Janeiro, RJ: LAV, Laboratório de Análise da Violência (LAV-UERJ).

Cooperman, Alicia (2020). "Trading Favors: Local Politics and Development in Brazil". Working Paper, p. 81.

Córdova, Abby (Apr. 2019). "Living in Gang-Controlled Neighborhoods: Impacts on Electoral and Nonelectoral Participation in El Salvador". Latin American Research Review 54.1, p. 201.

Cox, Gary W. (May 2015). "Electoral Rules, Mobilization, and Turnout". Annual Review of Political Science 18.1, pp. 49-68.

Cox, Gary W., Jon H. Fiva, and Daniel M. Smith (Apr. 2020). "Measuring the Competitiveness of Elections". Political Analysis 28.2, pp. 168-185.

Crisp, Brian and Rachael E. Ingall (2002). "Institutional Engineering and the Nature of Representation: Mapping the Effects of Electoral Reform in Colombia". American Journal of Political Science 46.4, pp. 733-748.

Dal Bó, Ernesto, Pedro Dal Bó, and Rafael Di Tella (Feb. 2006). "“Plata o Plomo?": Bribe and Punishment in a Theory of Political Influence". American Political Science Review 100.1, pp. 41-53.

Daniele, Gianmarco and Gemma Dipoppa (Oct. 2017). "Mafia, elections and violence against politicians". Journal of Public Economics 154, pp. 10-33.

De Feo, Giuseppe and Giacomo Davide De Luca (Aug. 2017). "Mafia in the Ballot Box". American Economic Journal: Economic Policy 9.3, pp. 134-167.

Dell, Melissa (June 2015). "Trafficking Networks and the Mexican Drug War". American Economic Review 105.6, pp. 1738-1779.

Dipoppa, Gemma (Feb. 2021). How Criminal Organizations Expand to Strong States: Migrant Exploitation and Political Brokerage in Northern Italy. preprint. Politics and International Relations.

Duran-Martinez, Angelica (Dec. 2017). The Politics of Drug Violence: Criminals, Cops and Politicians in Colombia and Mexico. Unabridged edition. Oxford University Press.

Eaton, Kent (Oct. 2006). "The Downside of Decentralization: Armed Clientelism in Colombia". Security Studies 15.4, pp. 533-562.

Fujiwara, Thomas and Leonard Wantchekon (Oct. 2013). "Can Informed Public Deliberation Overcome Clientelism? Experimental Evidence from Benin". American Economic Journal: Applied Economics 5.4, pp. 241-255.

Gallego, Jorge (Mar. 2018). "A Theory of Armed Clientelism". PhD thesis. Rosario, Argentina: University of Rosario.

Gambetta, Diego (1996). The Sicilian Mafia: the business of private protection. 1. Harvard Univ. Press paperback ed. Cambridge, Mass.: Harvard Univ. Press.

Gans-Morse, Jordan, Sebastián Mazzuca, and Simeon Nichter (2014). "Varieties of Clientelism: Machine Politics during Elections". American Journal of Political Science 58.2, pp. $415-432$. 
Gay, Robert (1993). Popular Organization and Democracy in Rio de Janeiro: A Tale of Two Favelas. Philadelphia: Temple University Press.

- (1999). "The Broker and the Thief: A Parable (Reflections on Popular Politics in Brazil)". Luso-Brazilian Review 36.1, pp. 49-70.

Geys, Benny (Dec. 2006). "Explaining voter turnout: A review of aggregate-level research". Electoral Studies 25.4, pp. 637-663.

Göbel, Christian (2004). "Combating "Black Gold" under Chen Shui-bian", p. 18.

Gottlieb, Jessica and Katrina Kosec (Feb. 2019). "The Countervailing Effects of Competition on Public Goods Provision: When Bargaining Inefficiencies Lead to Bad Outcomes". American Political Science Review 113.1, pp. 88-107.

Gottlieb, Jessica and Horacio Larreguy (Jan. 2020). "An Informational Theory of Electoral Targeting in Young Clientelistic Democracies: Evidence from Senegal". Quarterly Journal of Political Science 15.1, pp. 73-104.

Gunst, Laurie (Mar. 1996). Born Fi' Dead: A Journey Through The Jamaican Posse Underworld. Macmillan.

Hicken, Allen and Noah L. Nathan (May 2020). "Clientelism's Red Herrings: Dead Ends and New Directions in the Study of Nonprogrammatic Politics". Annual Review of Political Science 23.1, pp. 277-294.

Hidalgo, F. Daniel and Benjamin Lessing (2015). "Endogenous State Weakness: Paramilitaries and Electoral Politics". Working Paper, pp. 1-47.

Hill, Peter (Feb. 2004). "The Changing Face of the Yakuza". Global Crime 6.1, pp. 97-116.

Holland, Alisha C. (2016). "Forbearance". American Political Science Review 110.2, pp. 115.

Holland, Alisha C. and Brian Palmer-Rubin (Aug. 2015). "Beyond the Machine: Clientelist Brokers and Interest Organizations in Latin America". Comparative Political Studies 48.9, pp. 1186-1223.

Iacus, Stefano M, Gary King, and Giuseppe Porro (2009). Journal of Statistical Software cem: Software for Coarsened Exact Matching. Tech. rep.

Koter, Dominika (Apr. 2013). "King Makers: Local Leaders and Ethnic Politics in Africa". World Politics 65.2, pp. 187-232.

Kramon, Eric (July 2016). "Electoral Handouts as Information: Explaining Unmonitored Vote Buying". World Politics 68.3, pp. 454-498.

- (May 2019). "Ethnic group institutions and electoral clientelism". Party Politics 25.3, pp. 435-447.

LeBas, Adrienne (Sept. 2013). "Violence and Urban Order in Nairobi, Kenya and Lagos, Nigeria". Studies in Comparative International Development 48.3, pp. 240-262.

Lessing, Benjamin (2020). "Conceptualizing Criminal Governance". Perspectives on Politics, pp. $1-20$.

Lessing, Benjamin, Douglas Block, and Elayne Stecher (2019). "Criminal Governance in Latin America: An Empirical Approximation". 
Magaloni, Beatriz, Edgar Franco-Vivanco, and Vanessa Melo (May 2020). "Killing in the Slums: Social Order, Criminal Governance, and Police Violence in Rio de Janeiro". American Political Science Review 114.2, pp. 552-572.

Magaloni, Beatriz, Gustavo Robles, et al. (June 2020). "Living in Fear: The Dynamics of Extortion in Mexico's Drug War". Comparative Political Studies 53.7, pp. 1124-1174.

Mainwaring, Scott (1998). "Party systems in the third wave". Journal of Democracy.

Mainwaring, Scott, Timothy J. Power, and Fernando Bizzarro (Feb. 2018). "The Uneven Institutionalization of a Party System: Brazil*". Party Systems in Latin America. Ed. by Scott Mainwaring. 1st ed. Cambridge University Press, pp. 164-200.

Mares, Isabela and Lauren Young (May 2016). "Buying, Expropriating, and Stealing Votes". Annual Review of Political Science 19.1, pp. 267-288.

Muñoz Chirinos, Paula (2019). Buying audiences: clientelism and electoral campaigns when parties are weak. Cambridge, United Kingdom ; New York, NY: Cambridge University Press.

Murillo, M. Victoria, Virginia Oliveros, and Rodrigo Zarazaga (Apr. 2021). "The Most Vulnerable Poor: Clientelism Among Slum Dwellers". Studies in Comparative International Development.

Nascimento, Claudia Cerqueira do (Nov. 2017). "Igreja como partido: capacidade de coordenação eleitoral da Igreja Universal do Reino de Deus". Thesis.

Nichter, Simeon (Feb. 2008). "Vote Buying or Turnout Buying? Machine Politics and the Secret Ballot". American Political Science Review 102.1, pp. 19-31.

- (2018). Votes for Survival: Relational Clientelism in Latin America. Cambridge Studies in Comparative Politics. Cambridge: Cambridge University Press.

Novaes, Lucas M. (2018). "Disloyal Brokers and Weak Parties". American Journal of Political Science 62.1, pp. 84-98.

Olson, Mancur (1993). "Dictatorship, democracy, and development". The American Political Science Review 87.3, pp. 567-576.

Osorio, J. (2015). "The Contagion of Drug Violence: Spatiotemporal Dynamics of the Mexican War on Drugs". Journal of Conflict Resolution 59.8.

Perlman, Janice (June 2010). Favela: Four Decades of Living on the Edge in Rio de Janeiro. Oxford University Press.

Ricci, Fernando (Sept. 2020). De Dilma a Bolsonaro: como votam as favelas do Rio.

Rueda, Miguel R. (2017). "Small Aggregates, Big Manipulation: Vote Buying Enforcement and Collective Monitoring". American Journal of Political Science 61.1, pp. 163-177.

Satriano, Nicolas (Oct. 2020). Rio tem 3,7 milhões de habitantes em áreas dominadas pelo crime organizado; milícia controla $57 \%$ da área da cidade, diz estudo - Rio de Janeiro.

Scheiner, Ethan (2007). "Clientelism in Japan: the importance and limits of institutional explanations". Patrons, Clients, and Policies. Ed. by Herbert Kitschelt and Steven I. Wilkinson. Cambridge: Cambridge University Press, pp. 276-297.

Smith, Daniel M. (Apr. 2018). "Electoral Systems and Voter Turnout". The Oxford Handbook of Electoral Systems. Ed. by Erik S. Herron, Robert J. Pekkanen, and Matthew S. Shugart. Oxford University Press, pp. 192-212. 
Stokes, Susan C. et al. (2013). Brokers, Voters, and Clientelism: The Puzzle of Distributive Politics. Cambridge: Cambridge University Press.

Tajima, Yuhki (May 2018). "Political Development and the Fragmentation of Protection Markets". Journal of Conflict Resolution 62.5, pp. 1100-1126.

Trejo, Guillermo and Sandra Ley (Sept. 2019). "High-Profile Criminal Violence: Why Drug Cartels Murder Government Officials and Party Candidates in Mexico". British Journal of Political Science, pp. 1-27.

- (2020). Votes, Drugs, and Violence: The Political Logic of Criminal Wars in Mexico. Cambridge Studies in Comparative Politics. Cambridge: Cambridge University Press.

Weitz-Shapiro, Rebecca (2012). "What Wins Votes: Why Some Politicians Opt Out of Clientelism". American Journal of Political Science 56.3, pp. 568-583.

Yashar, Deborah J. (Dec. 2018). Homicidal Ecologies: Illicit Economies and Complicit States in Latin America. Cambridge University Press.

Zaluar, Alba (1994). A Máquina e a Revolta - As Organizações Populares e o Significado da Pobreza. 2nd ed. São Paulo: Editora Brasiliense.

- (2007). "Democratização inacabada: fracasso da segurança pública". Estudos Avançados 21.61, pp. 31-49.

Zarazaga, S. J. Rodrigo (2014). "Brokers Beyond Clientelism: A New Perspective Through the Argentine Case". Latin American Politics and Society 56.3, pp. 23-45. 


\section{A1 Electoral Assignment}

This section describes the exogenous ballot box assignment procedure. I leverage as-if random assignment to ballot boxes to calculate the share of favela voters that vote in each polling station. The polling station assignment process in Brazil is territory-based, but a person's residential address is not deterministic in predicting which ballot box they will be voting at. Instead, residential address is only deterministic in predicting which electoral zone a voter will be in, which is still a very high-level unit of analysis. In cities, an electoral zone may encompass several neighborhoods, while in rural parts of the country, a zone may include multiple municipalities. zones contain many polling stations, which each contain multiple ballot boxes, as shown in Figure A1. The number of ballot boxes in a polling station depends on the capacity of the building itself and population dynamics in that particular area.

Figure A1: Electoral Administration Levels in Brazil

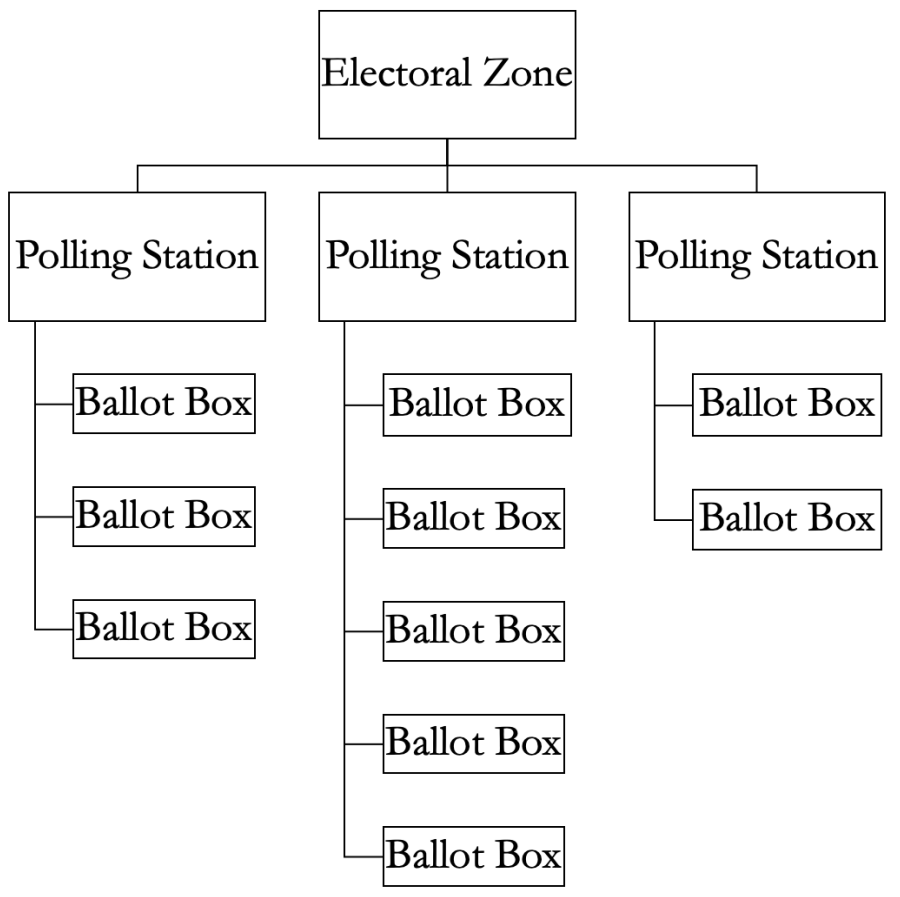

The assignment process proceeds in the following way. Each year when new voters are added to the voter list for a particular zone, a federal-level bureaucrat assigns the voter to a ballot box in their zone. Ballot box assignment stays constant year-to-year unless the voter moves and changes their registration address or is removed from the voter list. The federal bureaucrats in charge of the ballot box assignment process balance two priorities when assigning voters to their ballot boxes. ${ }^{40}$ First, the bureaucrat tries to assign them to

\footnotetext{
${ }^{40} \mathrm{I}$ have asked why a federal bureaucrat is in charge of this when the election is administered at the state
} 
a polling station nearest their residential address. Second, the bureaucrat tries to keep all ballot boxes balanced with more or less the same number of voters, especially among ballot boxes that are in the same polling station. The bureaucrats create new ballot boxes and fill them with new voters when they are approaching capacity at existing ballot boxes. Many polling places (schools, community centers, churches, etc.) have multiple ballot boxes - if the bureaucrat is assigning a voter to ballot box near their house, which ballot box within a polling station does the bureaucrat choose? In interviews with these bureaucrats, it appears that the assignment process is as-if random, conditional on polling station. If there are multiple ballot boxes not at capacity within that polling station, the bureaucrat is agnostic as to which one the voter votes in. One very common consequence of this assignment process is that teenage new voters are assigned to different ballot boxes - and sometimes different polling stations - than their parents, despite living under the same roof.

The residential address-to-ballot box assignment problem is particularly thorny for voters that live in favelas. Common polling station locations are schools, banks, or other government buildings that have high occupancy levels, comply with accessibility building codes, and can provide sufficient privacy to each precinct. Often, favelas do not have a building that complies with these regulations, or if they do, it is not large enough to accommodate all favela residents. The combination of poor building quality in favelas and the high population density means that favela residents often need to descend the hill and vote in the closest polling station to the favela boundary, which may also include non-favela low- or middle-class voters. Empirically, this is problematic for measuring how favela residents vote because one does not know which polling stations they travel to in order to case a ballot or how integrated favela residents are with other voters.

Figure A2 illustrates this problem in the case of the Santa Marta favela. Santa Marta is a favela in the middle of the wealthy South Zone of the city, but as shown in the map, there is not a single polling station inside of Santa Marta. However, there are several polling stations within 500, even 200 meters of the favela boundaries. There is no public information about which polling station(s) Santa Marta residents are more likely to vote at versus which ones their wealthy neighbors are more likely to vote at, which is why all previous research attempting to map favelas onto voting outcomes have followed the same method: create an indicator variable for whether or not a polling station falls within a favela buffer zone, ranging from 250 to 1000 meters outside the perimeter of the favela (Hidalgo and Lessing 2015; Nascimento 2017; Ricci 2020). In the example shown in Figure A2, all polling stations (and ballot boxes within polling stations) would take on a value of " 1 " for being within a 1000 meter buffer zone of a favela.

My data reveals that there are some ballot boxes in this 1000 meter range that only contain $6 \%$ or fewer favela voters. In Santa Marta, in Figure A2, the primary school Escola México, is where a majority of Santa Marta residents vote. But between the seven ballot boxes inside Escola México, one is nearly exclusively Santa Marta residents (75\% favela voters) while one is a mix of Santa Marta residents and the nearby middle class (32\% favela

level. Apparently the federal organ (Supreme Electoral Tribunal, TSE) has the software and human capital to do the assignments nationwide in a more efficient way than delegating it to the state-level electoral courts. 
Figure A2: Polling Stations near Santa Marta Favela

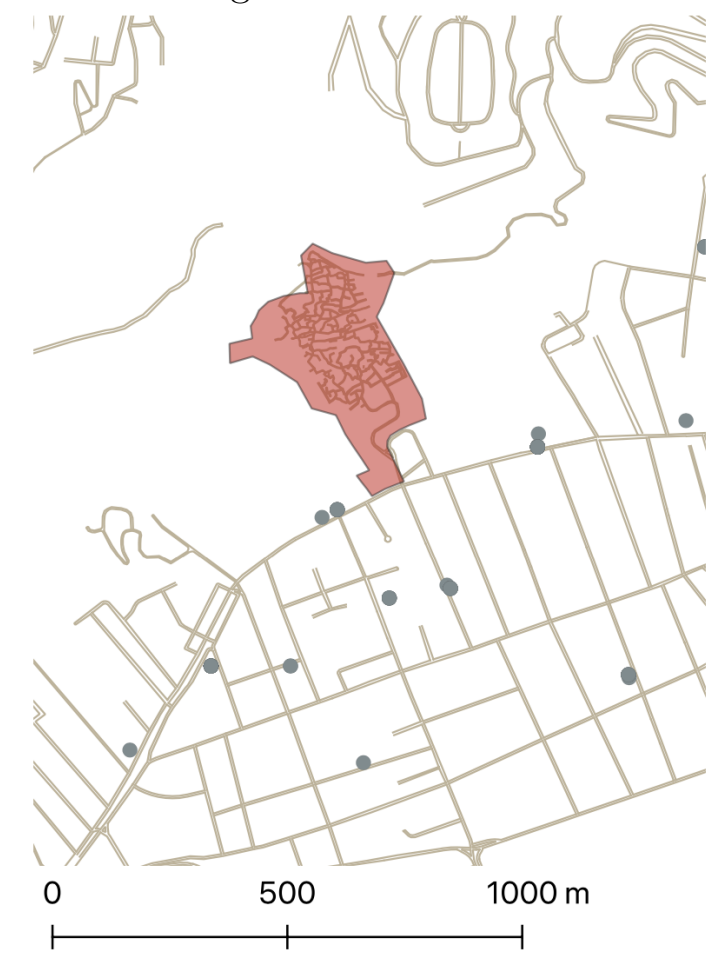

residents). In the polling station closest to Santa Marta, the German School, Santa Marta favela residents make up a maximum of $6 \%$ of voters in each of the 14 ballot boxes. 


\section{A2 Criminal Governance Dataset}

Subsection A2.1 describes the dataset construction. Subsection A2.2 provides sample images of the blog I used to classify favelas' criminal governance.

\section{A2.1 Data Construction}

The final dataset I analyze measures criminal dominance at the favela-month level across favelas in the city of Rio de Janeiro. I compile this dataset in the following steps.

1. I scraped articles from the blog titled Crimes News $R J$, a local Portuguese-language blog written by an anonymous author. The blog reports on criminal group conflict, turf wars, conflict with the police, and tracks biographic details of top drug traffickers in the greater metropolitan area of Rio de Janeiro. Though the blog's author is anonymous, it is widely recognized as a credible source and receives numerous tips through the website or its' social media (mainly YouTube and Twitter) channels. I first heard about the blog while interviewing state-level officials in the Ministry of Public Security in 2016. The officers praised the blog for accurately reporting which criminal factions were present in which neighborhoods and claimed that the information written was consistent with the classified intelligence information used by the police.

2. I process the text data in the blog posts by noting a common pattern that the author used when referring to a criminally-governed favela. Following the name of the favela, the author would write the name or abbreviation of the criminal faction in parentheses. I used this writing convention as a heuristic to begin identifying each favela-gang pair. The author used six abbreviations to denote different types of criminal governance: three for the drug traffickers ((ADA), (CV), (TCP)) and three for the milícias that the author used interchangeably ((ML), (MIL), (MILICIA)). I used these six faction identifiers to create a new dataframe with the date, faction, and the four words prior to the first parentheses, which contains the name of the favela.

3. I then begin building a dictionary of favela names, alternative names, and nicknames. The Instituto Pereira Passos (IPP), a municipal city planning and data collection agency, keeps and updates an annual registry of all favelas in the municipality of Rio de Janeiro. I used their list of names of favelas as a starting place to begin building the dictionary.

While there are official names for favelas, there are many variations of names or nicknames that make exact string matching challenging. For example, there is a favela named Morro São João (São João hill) and a different one named Comunidade São João, but residents of Rio de Janeiro may refer to either or both just as São João. Even more complicated are the unofficial nicknames that residents, including the blog's author, use that deviate from the official name. For example, there is a large favela named Juramento in the city of Rio de Janeiro. Colloquially, the small favela buttressing Juramento is called Juramentinho (little Juramento), but the official name registered with 
IPP is Parque Nova Maracá. I expand on IPP's list of official favela names to build a dictionary of names and alternative names that account for colloquialisms, nicknames, and spelling errors.

I also build dictionaries to identify smaller favelas by their complexes. There are several complexes of favelas across the city, which are large agglomerations of several side-by-side favelas that are commonly (but not always) under the same criminal rule. A famous example is Complexo do Alemão (German complex), which is a complex of nearly a dozen favelas, including the complex's nuclei, Morro do Alemão (German hill). This is useful for identifying the minor favelas that may not appear individually in the blog, but whose criminal governance can be deduced by the greater complex they pertain to.

4. I then match each date-faction-favela pair from Step 2 with my list of favela names, alternative names, and complexes. I hand-coded all of the blog post entries that I was not able to match using official names or alternative names in my dictionaries.

5. Lastly, I aggregate the data in favela-month format. For any given favela-month, if the favela was written about, they appear in my database alongside the governing faction. In the vast majority of cases, there was only one governing faction reported per favela-month period. However, when a favela takeover was successful, the blog author began referring to the favela's new criminal faction in the parenthetical reference. In the case of a takeover, I classify the favela-month observation according to the new criminal group in power and, separately, denote that a turnover happened during this favela-month.

I impute criminal dominance when favelas are not discussed every month in the blog but appear to maintain the same governing faction. For example, if a favela entered into the database for the first time in February 2015, is not written about again until August 2015, but the faction remains the same in August as it was in February, I code March 2015 through July 2015 as that same faction. I believe this risk of error is low in this case, because a criminal turnover and leadership scrabble is precisely the type of information that would be written about in the blog. I think it is far more likely that favelas are not written about when business is as usual.

For each favela-month, I denote the governing faction or impute it, according to these coding rules.

\section{A2.2 The Crimes News RJ blog}

Figure A3 shows a sample blog post from Crimes News RJ. Faction identifiers are shown parenthetically in the text, preceded by the favela name. 
Figure A3: Sample Blog Posts with Favela Identifiers

\section{Soldados da Cidade Alta gravam vídeos}

debochando dentro da Penha

agosto 05, 2021

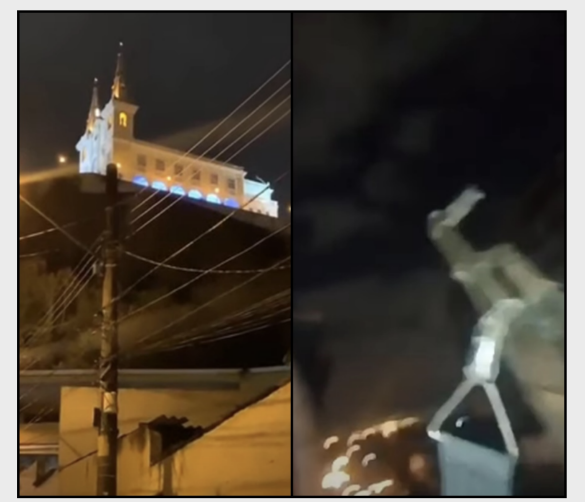

Apesar dos ânimos entre os traficantes da Penha (CV) e Cidade Alta (TCP) esfriaram nos últimos meses, em questăo de baques e invasões, os traficantes que se auto intitulam como soldados do "Complexo do Israel", foram até o Complexo da Penha.

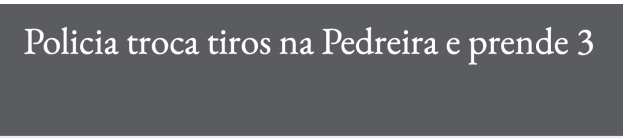

agosto 04,2021
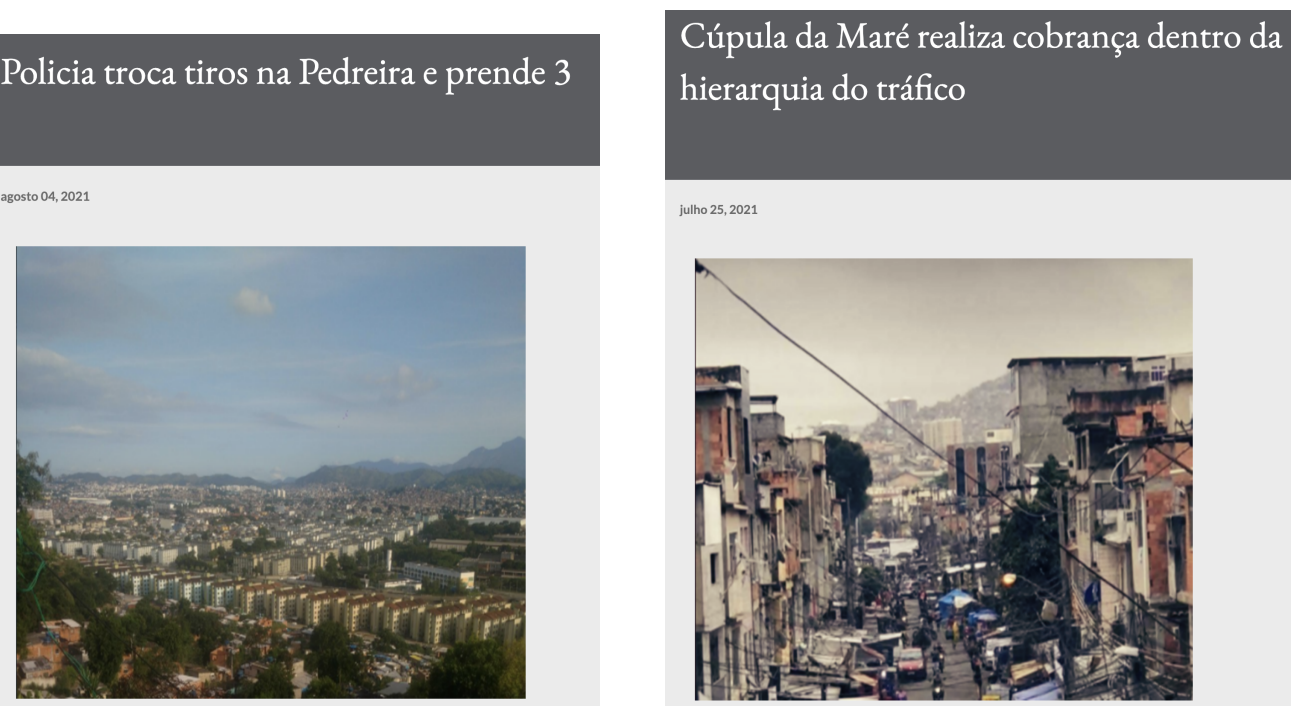

Ss policiais do $12^{\circ} \mathrm{BPM}$ (Niterói) relataram que o GAT conseguiu balear 2 suspeitos de envolvimento com o tráfico no Morro do Palácio (CV) no Ingá, região sul da cidade de Niterói.

GAT troca tiros e prende 2 suspeitos no Morro do Palácio
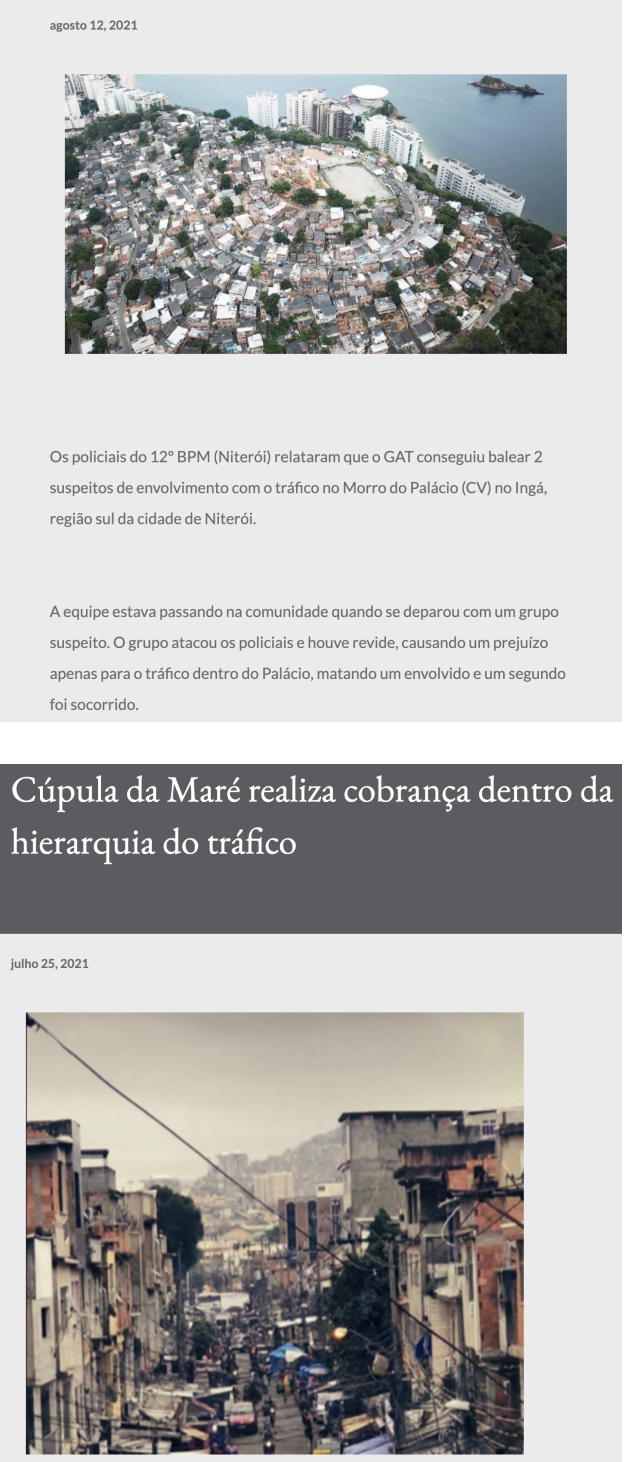

Nesta terça-feira os Policiais do $41^{\circ} \mathrm{Bpm}$ (Irajá) entraram em confronto no Morro da Pedreira (TCP) em Costa Barros, na zona norte do Rio de Janeiro.

Segundo informaçōes, mais uma cobrança interna dentro do tráfico fo realizada entre as lideranças da comunidade da Nova Holanda (CV), no Complexo da Maré, na zona norte do Rio de Janeiro.

Note: Figures show sample blog posts with titles, cover photo, and the first few sentences of the post. The faction identifiers (CV) and (TCP) are shown, preceded by the names of the favelas. 


\section{A2.3 DiD Robustness}

As an alternative strategy to measure changes in criminal governance over time, I leverage the staggered implementation of a large-scale public security reform ${ }^{41}$ to examine changes in voting behavior as communities transition from criminal governance to state governance. The UPP policy was centered on militarized police raids in favelas that began by chasing drug traffickers out of favelas and (theoretically) culminated with the state retaking control of all governance functions in the favela. In the short-run, post-raid, the state was incredibly successful of ridding the favelas of criminal rule. For this analysis, I define the sample as the 649 polling stations where residents from five large favelas vote: Vila Cruzeiro, Parque Proletário, Rocinha, Jacarezinho, and Manguinhos. All five favelas were included in the UPP reform and raided by police in the three months before or after the 2012 municipal election (three before, two after). They are also some of the largest favelas in the city by population, and were considered strongholds for various drug trafficking gangs.

I use Equation 2 to estimate the model. In this case, the control group is not one where criminal groups are scrambling for power, it is favelas where the state has taken back governing power. The variable CrimControl $_{f}$ takes on a value of one for the favelas that had strong criminal governance during the elections (Jacarezinho and Manguinhos), while it takes on a value of zero for those whose criminal dominance was interrupted by the UPP before the election (Parque Proletário, Vila Crzeiro, Rocinha). $\beta_{1}$ is the coefficient of interest.

Table A1 shows that favela voters are more likely to vote in bloc when they live under criminal governance, and this effect disappears when criminal regimes are displaced. A weakening of criminal control prior to an election is associated with a more open, competitive electoral playing field than when stable criminal regimes govern voters.

\footnotetext{
${ }^{41}$ Police Pacifying Units or UPPs, described in Magaloni, Franco-Vivanco, et al. (2020)).
} 
Table A1: Effect of criminal governance on voting over time (UPP Robustness)

\begin{tabular}{lccc}
\hline \hline & \multicolumn{3}{c}{ Dependent variable: } \\
\cline { 2 - 4 } & HHI & turnout & NCand \\
& $(1)$ & $(2)$ & $(3)$ \\
\hline Stable $\times 2012$ & $0.023^{* * *}$ & -0.006 & $-3.261^{* *}$ \\
& $(0.002)$ & $(0.006)$ & $(1.427)$ \\
Stable & $-0.008^{* *}$ & $-0.027^{* *}$ & 2.936 \\
& $(0.004)$ & $(0.012)$ & $(2.539)$ \\
2012 & & & -1.353 \\
& $-0.012^{* * *}$ & $-0.014^{* *}$ & $(1.325)$ \\
ShareFavela & $(0.002)$ & $(0.006)$ & $-1.014^{*}$ \\
& & & $(0.522)$ \\
& $\left(0.003^{* * *}\right.$ & 0.002 & 1,298 \\
Observations & 1,298 & $(0.002)$ & 0.613 \\
$\mathrm{R}^{2}$ & 0.577 & 1,298 & 0.589 \\
Adjusted $\mathrm{R}^{2}$ & 0.552 & 0.264 & 0.219 \\
\hline \hline Note: & & ${ }^{*} \mathrm{p}<0.1 ;{ }^{* *} \mathrm{p}<0.05 ;{ }^{* * *} \mathrm{p}<0.01$ \\
\end{tabular}




\section{A3 Additional Tables}

Table A2: Robustness Controlling for Criminal Faction

\begin{tabular}{lccc}
\hline \hline & \multicolumn{3}{c}{ Dependent variable: } \\
\cline { 2 - 4 } & Turnout & HHI & N Candidates \\
& $(1)$ & $(2)$ & $(3)$ \\
\hline ShareFavela & $0.0024^{*}$ & $0.0002^{* * *}$ & $-0.1901^{* *}$ \\
& $(0.0012)$ & $(0.00005)$ & $(0.0559)$ \\
CV & & & \\
& -0.4917 & 0.2802 & 0.8105 \\
& $(1,270.3)$ & $(1,049.8)$ & $(248,226.8)$ \\
MILICIA & -1.773 & 1.978 & 2.930 \\
& $(1,049.0)$ & $(239.7)$ & $(846,653.6)$ \\
TCP & 1.201 & -2.066 & -1.967 \\
& $(2,103.9)$ & $(1,192.4)$ & $(686,801.0)$ \\
& & & \\
Favela FE & $\checkmark$ & $\checkmark$ & $\checkmark$ \\
Polling Station FE & $\checkmark$ & $\checkmark$ & $\checkmark$ \\
Yearly FE & $\checkmark$ & $\checkmark$ & 105,352 \\
Observations & 105,352 & 105,352 & 0.534 \\
$\mathrm{R}^{2}$ & 0.154 & 0.601 & \\
\hline \hline
\end{tabular}

Note: Alternative estimates of Equation 1 that control for which criminal faction dominates the polling station, reported in Figure 7. The ShareFavela regressor is standardized. I include favela, polling station, and yearly fixed effects and pool the regression across four election-years: 2008, 2012, 2016, and 2020.

Standard errors are clustered at the level of randomization, the polling station-year level. ${ }^{*} \mathrm{p}<0.1$;

$$
{ }^{* *} \mathrm{p}<0.05 ;{ }^{* * *} \mathrm{p}<0.01
$$


Table A3: Robustness Controlling for Type of Criminal Faction

\begin{tabular}{lccc}
\hline \hline & \multicolumn{3}{c}{ Dependent variable: } \\
\cline { 2 - 4 } & Turnout & HHI & N Candidates \\
& $(1)$ & $(2)$ & $(3)$ \\
\hline ShareFavela & $0.0024^{* *}$ & $0.0002^{* *}$ & $-0.1901^{* *}$ \\
& $(0.0011)$ & $(0.00005)$ & $(0.0559)$ \\
MILICIA & & & 1.645 \\
& $-0.9900^{* * *}$ & 0.9129 & $(592,505.5)$ \\
\hline Favela FE & $(0.00001)$ & $(987.9)$ & $\checkmark$ \\
Polling Station FE & & & $\checkmark$ \\
Yearly FE & $\checkmark$ & $\checkmark$ & $\checkmark$ \\
Observations & $\checkmark$ & $\checkmark$ & 105,352 \\
$\mathrm{R}^{2}$ & 105,352 & 105,352 & 0.534 \\
\hline \hline
\end{tabular}

Note: Alternative estimates of Equation 1 that control for which type of criminal faction (of which there are two: drug traffickers and milicias), reported in Figure 7. The ShareFavela regressor is standardized. I include favela, polling station, and yearly fixed effects and pool the regression across four election-years:

2008, 2012, 2016, and 2020. Standard errors are clustered at the level of randomization, the polling station-year level. ${ }^{*} \mathrm{p}<0.1 ;{ }^{* *} \mathrm{p}<0.05 ;{ }^{* * *} \mathrm{p}<0.01$ 
Table A4: Robustness Controlling for Distance to Favela

\begin{tabular}{lccc}
\hline \hline & \multicolumn{3}{c}{ Dependent variable: } \\
\cline { 2 - 4 } & Turnout & HHI & N Candidates \\
& $(1)$ & $(2)$ & $(3)$ \\
\hline ShareFavela & $0.0024^{*}$ & $0.0002^{* *}$ & $-0.2008^{* *}$ \\
& $(0.0009)$ & $(0.00006)$ & $(0.0622)$ \\
& & & \\
$\log ($ meters) & -0.0002 & 0.00005 & -0.0554 \\
& $(0.00009)$ & $(0.00003)$ & $(0.0507)$ \\
& & & $\checkmark$ \\
Favela FE & $\checkmark$ & $\checkmark$ & $\checkmark$ \\
Polling Station FE & $\checkmark$ & $\checkmark$ & $\checkmark$ \\
Yearly FE & $\checkmark$ & $\checkmark$ & 107,357 \\
Observations & 107,357 & 107,357 & 0.536 \\
$\mathrm{R}^{2}$ & 0.155 & 0.602 & \\
\hline \hline
\end{tabular}

Note: Alternative estimates of Equation 1 that control for distance to the favela, reported in Figure 7. The ShareFavela regressor is standardized and distance to the favela is measured in logged meters. I include favela, polling station, and yearly fixed effects and pool the regression across four election-years: 2008, 2012, 2016, and 2020. Standard errors are clustered at the level of randomization, the polling station-year level. ${ }^{*} \mathrm{p}<0.1 ;{ }^{* *} \mathrm{p}<0.05 ;{ }^{* * *} \mathrm{p}<0.01$ 
Table A5: Robustness controlling for Spoiled Ballots

\begin{tabular}{lccc}
\hline \hline & \multicolumn{3}{c}{ Dependent variable: } \\
\cline { 2 - 4 } & Turnout & HHI & N Candidates \\
& $(1)$ & $(2)$ & $(3)$ \\
\hline ShareFavela & $0.0023^{*}$ & $0.0002^{* *}$ & $-0.1980^{* *}$ \\
& $(0.0009)$ & $(0.00006)$ & $(0.0576)$ \\
& & & \\
Spoiled & 0.3007 & -0.0237 & $32.08^{*}$ \\
& $(0.1533)$ & $(0.0460)$ & $(12.56)$ \\
& & & $\checkmark$ \\
Favela FE & $\checkmark$ & $\checkmark$ & $\checkmark$ \\
Polling Station FE & $\checkmark$ & $\checkmark$ & $\checkmark$ \\
Yearly FE & $\checkmark$ & $\checkmark$ & 105,352 \\
Observations & 105,352 & 105,352 & 0.534 \\
$\mathrm{R}^{2}$ & 0.154 & 0.601 & \\
\hline \hline
\end{tabular}

Note: Alternative estimates of Equation 1 that control for the share of ballots received at the polling place that were spoiled, reported in Figure 7. The ShareFavela regressor is standardized and the Share Spoiled is a fraction representing the number of spoiled ballots to total ballots cast in a polling station. I include favela, polling station, and yearly fixed effects and pool the regression across four election-years: 2008, 2012, 2016, and 2020. Standard errors are clustered at the level of randomization, the polling station-year level. ${ }^{*} \mathrm{p}<0.1 ;{ }^{* *} \mathrm{p}<0.05 ;{ }^{* * *} \mathrm{p}<0.01$ 
Table A6: Robustness Analyzing Relationship between Spoiled Ballots and Voting

\begin{tabular}{lccc}
\hline \hline & \multicolumn{3}{c}{ Dependent variable: } \\
\cline { 2 - 4 } & Turnout & HHI & N Candidates \\
& $(1)$ & $(2)$ & $(3)$ \\
\hline Spoiled & 0.3014 & -0.0236 & $32.02^{*}$ \\
& $(0.1535)$ & $(0.0460)$ & $(12.55)$ \\
& & & \\
\hline Favela FE & $\checkmark$ & $\checkmark$ & $\checkmark$ \\
Polling Station FE & $\checkmark$ & $\checkmark$ & $\checkmark$ \\
Yearly FE & $\checkmark$ & $\checkmark$ & $\checkmark$ \\
Observations & 105,352 & 105,352 & 105,352 \\
$\mathrm{R}^{2}$ & 0.155 & 0.601 & 0.536 \\
\hline \hline
\end{tabular}

Note: This is a placebo test of Equation 1 that tests if the share of spoiled ballots is a predictor of the three main outcome variables. The ShareFavela regressor is standardized and Share Spoiled is a fraction representing the number of spoiled ballots to total ballots cast in a polling station. I include favela, polling station, and yearly fixed effects and pool the regression across four election-years: 2008, 2012, 2016, and 2020. Standard errors are clustered at the level of randomization, the polling station-year level. ${ }^{*} \mathrm{p}<0.1$;

${ }^{* *} \mathrm{p}<0.05 ;{ }^{* * *} \mathrm{p}<0.01$ 
Table A7: Robustness Analyzing Results by Year

\begin{tabular}{|c|c|c|c|c|}
\hline & $(2008)$ & $(2012)$ & $(2016)$ & $(2020)$ \\
\hline \multirow[b]{3}{*}{ ShareFavela } & \multicolumn{4}{|c|}{ Dependent variable: } \\
\hline & \multicolumn{4}{|c|}{ Turnout } \\
\hline & $\begin{array}{l}0.0007^{* * *} \\
(0.0002)\end{array}$ & $\begin{array}{c}0.0019^{* *} \\
(0.0009)\end{array}$ & $\begin{array}{c}0.0045^{*} \\
(0.0024)\end{array}$ & $\begin{array}{l}0.0016^{* * *} \\
(0.0005)\end{array}$ \\
\hline \multirow[t]{2}{*}{$\mathrm{R}^{2}$} & 0.27488 & 0.17664 & 0.22202 & 0.50081 \\
\hline & \multicolumn{4}{|c|}{ HHI } \\
\hline ShareFavela & $\begin{array}{c}0.0004^{* * *} \\
(0.00006)\end{array}$ & $\begin{array}{c}0.0003^{* * *} \\
(0.00005)\end{array}$ & $\begin{array}{c}0.0002^{* * *} \\
(0.00004)\end{array}$ & $\begin{array}{c}0.0001^{* * *} \\
(0.00003)\end{array}$ \\
\hline \multirow[t]{2}{*}{$\mathrm{R}^{2}$} & 0.90863 & 0.90635 & 0.91650 & 0.90070 \\
\hline & \multicolumn{4}{|c|}{ N Candidates } \\
\hline ShareFavela & $\begin{array}{c}-0.2947^{* * *} \\
(0.0508)\end{array}$ & $\begin{array}{c}-0.2498^{* * *} \\
(0.0500)\end{array}$ & $\begin{array}{c}-0.2089^{* * *} \\
(0.0410)\end{array}$ & $\begin{array}{c}-0.0924^{* * *} \\
(0.0298)\end{array}$ \\
\hline$\underline{\mathrm{R}^{2}}$ & 0.66143 & 0.65258 & 0.63893 & 0.68843 \\
\hline Favela FE & $\checkmark$ & $\checkmark$ & $\checkmark$ & $\checkmark$ \\
\hline Polling Station FE & $\checkmark$ & $\checkmark$ & $\checkmark$ & $\checkmark$ \\
\hline Observations & 21,736 & 24,034 & 25,756 & 33,826 \\
\hline
\end{tabular}

Note: Alternative estimates of Equation 1 that analyzes the results by election-year. The ShareFavela regressor is standardized. I include favela and polling station fixed effects and cluster standard errors are clustered at the level of randomization, the polling station. ${ }^{*} \mathrm{p}<0.1 ;{ }^{* *} \mathrm{p}<0.05 ;{ }^{* *} \mathrm{p}<0.01$ 
Table A8: Robustness Analyzing Polling Stations Near Favelas

\begin{tabular}{lccc}
\hline \hline & \multicolumn{3}{c}{ Dependent variable: } \\
\cline { 2 - 4 } & Turnout & HHI & N Candidates \\
& $(1)$ & $(2)$ & $(3)$ \\
\hline ShareFavela & 0.0024 & $0.0002^{* *}$ & $-0.1802^{* *}$ \\
& $(0.0011)$ & $(0.00004)$ & $(0.0549)$ \\
& & & \\
\hline Favela FE & $\checkmark$ & $\checkmark$ & $\checkmark$ \\
Polling Station FE & $\checkmark$ & $\checkmark$ & $\checkmark$ \\
Yearly FE & $\checkmark$ & $\checkmark$ & $\checkmark$ \\
Observations & 86,970 & 86,970 & 86,970 \\
$\mathrm{R}^{2}$ & 0.139 & 0.630 & 0.522 \\
\hline \hline
\end{tabular}

Note: Alternative estimates of Equation 1 that considers the subset of polling stations that are located within 100 meters of the favela's border. The ShareFavela regressor is standardized. I include favela, polling station, and yearly fixed effects and pool the regression across four election-years: 2008, 2012, 2016, and 2020. Standard errors are clustered at the level of randomization, the polling station-year level.

${ }^{*} \mathrm{p}<0.1 ;{ }^{* *} \mathrm{p}<0.05 ;{ }^{* * *} \mathrm{p}<0.01$ 
Table A9: Robustness Analyzing Alternative Dependent Variables

\begin{tabular}{|c|c|c|c|c|c|}
\hline & \multicolumn{5}{|c|}{ Dependent variable: } \\
\hline & \multicolumn{5}{|c|}{ ShareTop5 } \\
\hline & $(1)$ & $(2)$ & $(3)$ & $(4)$ & $(5)$ \\
\hline ShareFavela & $\begin{array}{l}0.0008^{* * *} \\
(0.0001)\end{array}$ & $\begin{array}{l}0.0008^{* * *} \\
(0.0001)\end{array}$ & $\begin{array}{l}0.0008^{* * *} \\
(0.0001)\end{array}$ & $\begin{array}{c}0.0008^{* *} \\
(0.0001)\end{array}$ & $\begin{array}{c}0.0007^{* *} \\
(0.0001)\end{array}$ \\
\hline $\mathrm{CV}$ & & $\begin{array}{c}-0.8903 \\
(5,383.3)\end{array}$ & & & \\
\hline MILICIA & & $\begin{array}{c}-3.159 \\
(6,055.8)\end{array}$ & $\begin{array}{c}-1.760 \\
(2,646.3)\end{array}$ & & \\
\hline TCP & & $\begin{array}{c}2.132 \\
(5,668.2)\end{array}$ & & & \\
\hline $\log ($ meters $)$ & & & & $\begin{array}{c}0.00004 \\
(0.00006)\end{array}$ & \\
\hline Spoiled & & & & & $\begin{array}{c}0.3129^{*} \\
(0.1038)\end{array}$ \\
\hline Favela FE & $\checkmark$ & $\checkmark$ & $\checkmark$ & $\checkmark$ & $\checkmark$ \\
\hline Polling Station FE & $\checkmark$ & $\checkmark$ & $\checkmark$ & $\checkmark$ & $\checkmark$ \\
\hline Yearly FE & $\checkmark$ & $\checkmark$ & $\checkmark$ & $\checkmark$ & $\checkmark$ \\
\hline Observations & 105,352 & 105,352 & 105,352 & 105,352 & 105,352 \\
\hline $\mathrm{R}^{2}$ & 0.63569 & 0.63569 & 0.63569 & 0.63629 & 0.64726 \\
\hline
\end{tabular}

Note: Alternative estimates of Equation 1 that considers a different operationalization of the outcome for vote concentration. All models use the ShareTop5 outcome, which is the proportion of votes per ballot box the top five most voted candidates receive. The ShareFavela regressor is standardized and all models reported are the five point estimates shown in Figure 7. I include favela, polling station, and yearly fixed effects and pool the regression across four election-years: 2008, 2012, 2016, and 2020. Standard errors are clustered at the level of randomization, the polling station-year level. ${ }^{*} \mathrm{p}<0.1 ;{ }^{* *} \mathrm{p}<0.05 ;{ }^{* * *} \mathrm{p}<0.01$ 
Table A10: Robustness Analyzing Alternative Dependent Variables

\begin{tabular}{|c|c|c|c|c|c|}
\hline & \multicolumn{5}{|c|}{ Dependent variable: } \\
\hline & \multicolumn{5}{|c|}{ N Candidates Receiving $2+$ Votes } \\
\hline & $(1)$ & $(2)$ & $(3)$ & $(4)$ & $(5)$ \\
\hline ShareFavela & $\begin{array}{c}-0.0317 \\
(0.0229)\end{array}$ & $\begin{array}{c}-0.0445^{* * *} \\
(0.0146)\end{array}$ & $\begin{array}{c}-0.0404^{* * *} \\
(0.0072)\end{array}$ & $\begin{array}{c}-0.0471^{* *} \\
(0.0095)\end{array}$ & $\begin{array}{r}-0.0326 \\
(0.0250)\end{array}$ \\
\hline $\mathrm{CV}$ & & $\begin{array}{l}8.561^{* * *} \\
(1.062)\end{array}$ & & & \\
\hline MILICIA & & $\begin{array}{c}6.576^{* * *} \\
(0.2354)\end{array}$ & $\begin{array}{c}-0.9406 \\
(224,381.9)\end{array}$ & & \\
\hline TCP & & $\begin{array}{c}6.263^{* * *} \\
(0.0184)\end{array}$ & & & \\
\hline $\log ($ meters $)$ & & & & $\begin{array}{c}-0.0222 \\
(0.0324)\end{array}$ & \\
\hline Spoiled & & & & & $\begin{array}{c}3.016 \\
(6.206)\end{array}$ \\
\hline Favela FE & $\checkmark$ & $\checkmark$ & $\checkmark$ & $\checkmark$ & $\checkmark$ \\
\hline Polling Station FE & $\checkmark$ & $\checkmark$ & $\checkmark$ & $\checkmark$ & $\checkmark$ \\
\hline Yearly FE & $\checkmark$ & $\checkmark$ & $\checkmark$ & $\checkmark$ & $\checkmark$ \\
\hline Observations & 260,085 & 260,085 & 183,085 & 184,734 & 105,352 \\
\hline $\mathrm{R}^{2}$ & 0.47457 & 0.47468 & 0.47836 & 0.47947 & 0.46361 \\
\hline
\end{tabular}

Note: Alternative estimates of Equation 1 that considers a different operationalization of the outcome for

$\mathrm{N}$ candidates receiving votes. All models use the $N$ Candidates Receiving $2+$ Votes outcome, which is number of candidates per ballot box for city councillor that receive two or more votes. The ShareFavela regressor is standardized and all models reported are the five point estimates shown in Figure 7. I include favela, polling station, and yearly fixed effects and pool the regression across four election-years: 2008, 2012, 2016, and 2020. Standard errors are clustered at the level of randomization, the polling station-year level. ${ }^{*} \mathrm{p}<0.1 ;{ }^{* *} \mathrm{p}<0.05 ;{ }^{* * *} \mathrm{p}<0.01$ 
Table A11: Robustness Analyzing Alternative Dependent Variables

\begin{tabular}{|c|c|c|c|c|c|}
\hline & \multicolumn{5}{|c|}{ Dependent variable: } \\
\hline & \multicolumn{5}{|c|}{ N Candidates Receiving $5+$ Votes } \\
\hline & $(1)$ & $(2)$ & $(3)$ & $(4)$ & $(5)$ \\
\hline ShareFavela & $\left(1 \times 10^{-5}\right)^{0.0006^{* * *}}$ & $\begin{array}{c}-0.0051 \\
(0.0038)\end{array}$ & $\begin{array}{l}-0.0114^{* * *} \\
(0.0027)\end{array}$ & $\begin{array}{l}-0.0068^{* * *} \\
(0.0003)\end{array}$ & $\begin{array}{c}0.0017 \\
(0.0060)\end{array}$ \\
\hline $\mathrm{CV}$ & & $\begin{array}{l}4.009^{* * *} \\
(0.5597)\end{array}$ & & & \\
\hline MILICIA & & $\begin{array}{l}2.670^{* * *} \\
(0.0523)\end{array}$ & $\begin{array}{l}-0.4934 \\
(87,195.1)\end{array}$ & & \\
\hline $\mathrm{TCP}$ & & $\begin{array}{l}2.610^{* * *} \\
(0.0137)\end{array}$ & & & \\
\hline $\log ($ meters $)$ & & & & $\begin{array}{r}-0.0106 \\
(0.0122)\end{array}$ & \\
\hline Spoiled & & & & & $\begin{array}{c}-4.009 \\
(3.462)\end{array}$ \\
\hline Favela FE & $\checkmark$ & $\checkmark$ & $\checkmark$ & $\checkmark$ & $\checkmark$ \\
\hline Polling Station FE & $\checkmark$ & $\checkmark$ & $\checkmark$ & $\checkmark$ & $\checkmark$ \\
\hline Yearly FE & $\checkmark$ & $\checkmark$ & $\checkmark$ & $\checkmark$ & $\checkmark$ \\
\hline Observations & 260,085 & 260,085 & 183,085 & 184,734 & 105,352 \\
\hline $\mathrm{R}^{2}$ & 0.47457 & 0.47468 & 0.47836 & 0.47947 & 0.46361 \\
\hline
\end{tabular}

Note: Alternative estimates of Equation 1 that considers a different operationalization of the outcome for

$\mathrm{N}$ candidates receiving votes. All models use the $N$ Candidates Receiving $5+$ Votes outcome, which is number of candidates per ballot box for city councillor that receive five or more votes. The ShareFavela regressor is standardized and all models reported are the five point estimates shown in Figure 7. I include favela, polling station, and yearly fixed effects and pool the regression across four election-years: 2008, 2012, 2016, and 2020. Standard errors are clustered at the level of randomization, the polling station-year level. ${ }^{*} \mathrm{p}<0.1 ;{ }^{* *} \mathrm{p}<0.05 ;{ }^{* * *} \mathrm{p}<0.01$ 